Review of

ECONOMICS

and

INSTITUTIONS
Review of Economics and Institutions

ISSN 2038-1379 DOI 10.5202/rei.v6i1.174

Vol. 6 - No. 1, Winter-Spring 2015 - Article 2

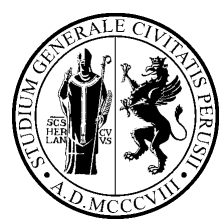

www.rei.unipg.it

\title{
Business Groups in Emerging Markets: Paragons or Parasites?
}

\author{
Tarun Khanna \\ Yishay Yafeh \\ Harvard Business School \\ Jerusalem School of \\ Business Administration
}

\begin{abstract}
Diversified business groups, consisting of legally independent firms operating across diverse industries, are ubiquitous in emerging markets. Groups around the world share certain attributes but also vary substantially in structure, ownership, and other dimensions. This paper proposes a business group taxonomy, which is used to formulate hypotheses and present evidence about the reasons for the formation, prevalence, and evolution of groups in different environments. In interpreting the evidence, the authors pay particular attention to two aspects neglected in much of the literature: the circumstances under which groups emerge and the historical evidence on some of the questions addressed by recent studies. They argue that business groups are responses to different economic conditions and that, from a welfare standpoint, they can sometimes be "paragons" and, at other times, "parasites." The authors conclude with an agenda for future research.
\end{abstract}

This paper has been published as Journal of Economic Literature Vol. 45 (2007) No. 2, 331-372. The Review of Economics and Institutions is grateful to the Journal of Economic Literature for having authorized its reproduction here.

Recommended Citation

Khanna, T., Yishay, Y. (2015). Business Groups in Emerging Markets: Paragons or Parasites? Review of Economics and Institutions, 6(1), Article 2. doi: 10.5202/rei.v6i1.174.

Retrieved from http://www.rei.unipg.it/rei/article/view/174 


\section{Introduction}

Diversified business (or corporate) groups are ubiquitous in emerging markets (e.g., Brazil, Chile, China, India, Indonesia, South Korea, Mexico, Pakistan, Thailand, and many more) and even in some developed economies (e.g., Italy, Sweden). These groups typically consist of legally independent firms, operating in multiple (often unrelated) industries, which are bound together by persistent formal (e.g., equity) and informal (e.g., family) ties. Varying degrees of participation by outside investors characterize many business groups around the world. Table 1 suggests that, in all countries for which data are available, the fraction of firms classified by domestic sources as group affiliated is substantial, ranging from about a fifth in Chile to about two-thirds in Indonesia. The table also indicates that, in virtually all emerging markets, group affiliated firms tend to be relatively large and economically important.

But groups around the world vary considerably in form: some are extremely diversified whereas others are more focused. In some groups there is considerable vertical integration and intragroup trade; in others, less. Some groups are deeply involved in banking and financial services, whereas others are not. Some of this diversity is illustrated in Table 2, which displays partial data on the extent of group diversification, vertical integration, and involvement in financial services in nine emerging markets. ${ }^{1}$ Groups in Chile, for example, are far more diversified than groups in South Korea, which, in turn, are more diversified than groups in Taiwan; groups in the Philippines are far more vertically integrated than groups in India and far more involved in financial services than groups in Thailand. Moving from structure to ownership and control, some business groups are vertically controlled ("pyramids"), whereas others are horizontally linked through cross shareholdings. The extent of family involvement also varies considerably across groups. Finally, in certain countries, business groups are a politically important force, enjoying close relations with the government; in others the relations between groups and governments tend to be more turbulent.

The ubiquity and diversity of business groups make the study of this institution fascinating. Conceptually, this hybrid organizational form between firm and market can shed new light on the theory of the firm and its boundaries. Empirically, the ubiquity of business groups outside the United States and the United Kingdom makes them relevant to a variety of fields

1 Group diversification is measured by the number of two-digit industries in which the group operates. Vertical integration is measured as follows: Group firms are classified into two-digit ISIC industries and, for each pair of firms $(x, y)$, we observe the fraction of inputs from xâs industry to yâs and vice versa. We then record the higher value for each pair and average over all pairs in the group to obtain the groupâs vertical integration index. Involvement in financial services is measured as the fraction of all group assets in group financial firms. See Khanna and Yafeh (2005) for further details on these measures. 
Table 1 - Group Affiliation Around the World

\begin{tabular}{|c|c|c|c|c|c|c|c|c|}
\hline & $\begin{array}{c}\text { Years } \\
\text { of } \\
\text { data }\end{array}$ & $\begin{array}{l}\text { Number } \\
\text { of firms }\end{array}$ & $\begin{array}{l}\text { Number } \\
\text { of group } \\
\text { affiliated } \\
\text { firms }\end{array}$ & $\begin{array}{l}\text { (Median size } \\
\text { of group } \\
\text { affiliated } \\
\text { firms)/ } \\
\text { (Median size } \\
\text { of } \\
\text { unaffiliated } \\
\text { firms) }\end{array}$ & $\begin{array}{l}\text { Median } \\
\text { ROA of } \\
\text { affiliated } \\
\text { firms } \\
\text { (percent) }\end{array}$ & $\begin{array}{c}\text { Median } \\
\text { ROA of } \\
\text { unaffiliated } \\
\text { firms } \\
\text { (percent) }\end{array}$ & $\begin{array}{l}\text { Median } \\
\text { standard } \\
\text { deviation } \\
\text { of ROA, } \\
\text { group } \\
\text { affiliated } \\
\text { firms } \\
\text { (percent) }\end{array}$ & $\begin{array}{c}\text { Median } \\
\text { standard } \\
\text { deviation } \\
\text { of ROA, } \\
\text { unaffiliated } \\
\text { firms } \\
\text { (percent) }\end{array}$ \\
\hline Argentina & 1990-97 & 25 & 11 & 5.5 & 3.9 & $7.8^{* *}$ & 3.7 & $4.9^{* *}$ \\
\hline Brazil & 1990-97 & 108 & 51 & 2.5 & 3.3 & $1.8^{* *}$ & 4.1 & 5.1 \\
\hline Chile & 1989-96 & 225 & 50 & 18.7 & 5.9 & $2.2^{*}$ & 4.4 & 4.1. \\
\hline India & 1990-97 & 5446 & 1821 & 4.4 & 11.7 & $9.6^{*}$ & 4.6 & $4.4^{*}$ \\
\hline Indonesia & 1993-95 & 236 & 153 & 2.8 & 7.3 & 7.8 & 1.9 & $2.5^{*}$ \\
\hline Israel & 1993-95 & 183 & 43 & 5.0 & 6.3 & $3.9^{*}$ & 2.1 & 2.6 \\
\hline South Korea & 1991-95 & 427 & 218 & 3.9 & 4.8 & 5.1 & 1.9 & $2.6^{*}$ \\
\hline Mexico & 1988-97 & 55 & 19 & 2.3 & 8.2 & 6.1 & 3.1 & 2.6 \\
\hline Philippines & 1992-97 & 148 & 37 & 3.4 & 7.3 & 4.0 & 2.5 & 2.9 \\
\hline Taiwan & 1990-97 & 178 & 79 & 2.0 & 5.1 & 6.2 & 1.7 & $2.3^{* *}$ \\
\hline Thailand & 1992-97 & 415 & 258 & 2.3 & 2.9 & $4.4^{*}$ & 4.3 & $4.9^{* *}$ \\
\hline Turkey & 1988-97 & 40 & 21 & 1.0 & 24.6 & 26.3 & 6.2 & 9.1 \\
\hline Prewar Japan & $1932-43$ & 58 & 17 & 6.8 & 5.5 & 6.4 & 4.4 & 7.1 \\
\hline
\end{tabular}

Notes: The table shows summary statistics on group risk and operating performance for twelve emerging markets as well as for prewar Japan. Firm numbers, as well as statistics on firm size (total assets) and median return on assets (ROA), are all based on the year for which we have maximal coverage for the country in question. In pre- war Japan, group affiliation refers to affiliation in the largest three zaibatsu only. Significance levels for the comparisons of medians are based on Wilcoxon signed-rank tests. Firms with profit rates above 100 percent or below -100 percent are excluded from the analysis. * and ${ }^{* *}$ denote a difference between group-affiliated and other firms that is significant at the 5 percent and 10 percent levels, respectively. See Khanna and Yafeh (2005) for data sources and for more information on the sample and variable definitions.

within economics, including industrial organization, corporate finance, development and growth, and even open-economy macro to the extent that it deals with financial crises.

In addition, the comparative study of business groups in emerging markets may shed new light on some economic phenomena in developed economies. For example, although many business groups are highly diversified, unlike American conglomerates each group firm is an independent entity, and the equity stake of outside investors can vary across group firms. Why are diversified entities in the United States organized as conglomerates rather than business groups? Is the answer related to economic and financial development? Or is it perhaps due to differences in the rule of law, social structure, or political economy? Is it due to unique historical developments in the United States? The study of business groups in emerging markets could potentially offer some answers. 
The present paper attempts to make three contributions to the literature on business groups. The first is motivated by the view that the diversity of business groups around the world is due to the diversity of the underlying conditions leading to their formation. This approach is at the basis of a novel taxonomy of business groups along three dimensions:

(1) Group structure: the extent of horizontal diversification; the extent of vertical integration; and the extent of involvement in the financial sector.

(2) Group ownership and control: the extent to which the group is pyramidal in structure; the extent to which it is family controlled.

(3) Group interaction with society: the nature of the interaction between business groups and the state; the extent of monopoly power wielded by groups.

This taxonomy is used to derive six testable hypotheses about the reasons for the formation of business groups, their prevalence in different economic environments, and the welfare implications associated with their presence. In general, the framework in which economic agents form business groups in response to the economic and institutional environment within which they operate is in the spirit of work by Aoki (2001) or Greif (2006), who emphasize that institutions should be analyzed within a particular economic context. Because groups arise for different reasons and in different environments, we argue that their impact on social welfare is ambiguous, even though much of the existing literature suggests that they are uniformly welfare-reducing: groups may sometimes play a positive role by making up for underdeveloped economic institutions, but they can also be detrimental to social welfare because of rent seeking or monopoly power. There is therefore no clear verdict on the extent to which groups should be viewed as "paragons" or "parasites," and the answer is likely to vary across countries, groups, and possibly time periods.

The second contribution of the present study is the presentation of new stylized data and evidence on several facets of business groups which go beyond the existing literature. In particular, we present comparable data on the origins and emergence of business groups around the world. This is key because group membership should generally be viewed as endogenous and because most of the empirical literature on business groups is plagued by lack of data on group origin. Another example of novel data in this paper is preliminary evidence supporting the view that groups do not only respond to their environment but also shape and influence it. Although econometric evidence on this point is almost entirely absent, historical evidence in several countries is supportive of this view. This dynamic effect of groups on their economic environment is sometimes socially welfare-enhancing, and sometimes not.

The third contribution of the present study is to question some of the conventional wisdom in the literature. For example, groups, we argue, are not purely rent-seeking organizations as some of the literature has por- 
Table 2 - Group Heterogeneity Around the World

\begin{tabular}{lccc}
\hline \hline Country & $\begin{array}{c}\text { Group } \\
\text { diversification }\end{array}$ & $\begin{array}{c}\text { Group vertical } \\
\text { integration }\end{array}$ & $\begin{array}{c}\text { Group assets in } \\
\text { financial firms }\end{array}$ \\
\hline Brazil & 1.4 & 0.04 & N/A \\
Chile & 5.1 & 0.06 & 0.24 \\
India & 4.2 & 0.04 & 0.05 \\
Indonesia & 2.1 & 0.04 & 0.45 \\
South Korea & 1.7 & 0.04 & $\mathrm{~N} / \mathrm{A}$ \\
Mexico & 2.7 & 0.02 & 0.05 \\
Philippines & 3.1 & 0.08 & 0.60 \\
Taiwan & 1.6 & 0.02 & 0.01 \\
Thailand & 3.5 & 0.04 & 0.35 \\
\hline \hline
\end{tabular}

Notes: Group diversification is measured as the number of two-digit industries in which the group operates. Group vertical integration is the average input-output coefficient across all pairs of firms within the group (see footnote 1), and involvement in financial services is measured as the fraction of all group assets in group financial firms. See Khanna and Yafeh (2005) for data sources and for more information on the sample and variable definitions.

trayed them. Nor should groups be equated with pyramids, and pyramids are not always the, or even $a$, way of disenfranchising minority shareholders.

The literature on business groups in economics and finance has focused primarily on two themes. The first regards business groups as diversified entities, and studies the relations between this feature and various questions in industrial organization and corporate finance. The second, more recent, research theme on business groups follows Shleifer and Vishny's (1997) survey on corporate governance and subsequent work by La Porta et al. (1997, 1998). Studies in this line of research regard business groups, especially their pyramidal forms, as a favorite setting for the study of conflicts of interests between controlling and minority shareholders; the latter's expropriation is often referred to as "tunneling." $\left.\right|^{2}$ Beside diversification and tunneling, a small number of economic studies emphasize rent seeking and the sometimes close relations between business groups and the governments of the countries in which they operate. An even smaller number of studies attempt to relate groups to monopoly power and imperfect competition.

Outside economics and finance, groups have attracted a lot of academic interest in sociology, where they are viewed as networks of social, not only economic, significance (e.g., Gerlach 1992; Granovetter 2005; Hamilton 1997; Keister 2004; Orrù et al., 1997). Studies of business groups are also common in business history, where the unit of analysis is typically the history of one

2 The term 'tunneling' has become popular following Johnson et al. (2000) who trace its origins to the expropriation of minority shareholders in the Czech Republic. 
group (e.g., Roberts 1973 on the house of Mitsui; Steers 1999 on the Hyundai group, and many more) or on groups in a single country (e.g., Amsden 1989's study of South Korea and its chaebol groups or Piramal 1998's study of Indian business houses). Although extensive, the literature on business groups leaves many interesting questions unanswered.

The present papers builds on our own earlier surveys of business groups - a short overview by Khanna (2000) on emerging markets and by Yafeh (2003) on Japan. There are also two complementary, concurrent surveys that readers should consult - Granovetter (2005) reviews the economic sociology literature, and Morck et al. (2005) discuss pyramidal groups and corporate governance.

The rest of the paper is organized around the taxonomy of business groups around the world: section 2 focuses on dimensions related to the structure of business groups; in section 3 we examine dimensions related to ownership and control; section 4 focuses on two dimensions of the interaction between business groups and society; and the con- cluding section, section 5, delineates a future research agenda. All sections contain one or more hypotheses derived from the taxonomy of business groups, which are followed by subsections presenting the existing evidence.

\section{Structure and Form of Business Groups}

\subsection{Structure of Business Groups: Diversification}

Prevailing managerial theories advocate that companies should discover their source of competitive advantage and remain true to it. This "conventional wisdom" is not based on unambiguous theoretical predictions: corporate diversification can be beneficial to shareholders if a firm has certain resources that can be profitably deployed outside the industry in which it operates, such as entrepreneurial skills, technology, etc. In addition, when equity markets function poorly, it may be possible to lower risk through diversification across industries. In contrast with these positive arguments for diversification, there are also theoretical foundations for the view that diversification can be harmful if it is driven by managerial objectives such as "empire building" or risk aversion, or if it leads to agency problems among division managers (e.g., Rajan et al., 2000; Scharfstein and Stein 2000). Empirically, the common view in the United States, that diversification "destroys shareholder value," has been supported by evidence on the relative performance of firms focused on a small number of industries in comparison with diversified firms-which suggests that, in the United States, the costs associated with diversification typically exceed the benefits. ${ }^{3}$

3 See surveys by Montgomery (1994) and Martin and Sayrak (2003). The association of diversification with a loss of firm value in modern U.S. data is sometimes called the 'di- 
The ubiquity of diversified (and often fairly successful) business groups in many countries outside the United States is therefore in sharp contrast with the prevailing conventional wisdom. Why then is diversification in the form of business groups so common in emerging markets? Leaving aside (for now) the question why the typical institutional mechanism for diversification is conglomerates in the United States and business groups in emerging markets, the following hypothesis offers one possible explanation:

Hypothesis 1: Diversified business groups should be more common in economies with less developed market institutions.

Hypothesis 1 is based on the conjecture that corporate focus need not necessarily be a good strategy in environments less economically developed than the United States, where the benefits of diversification may exceed the costs. The main reason is that some of the institutions that make diversification unnecessary or even harmful in developed economies do not exist or are underdeveloped in poorer countries. Capital markets are incomplete and may be plagued with informational and other problems, making risk reduction through diversification and the use of internal capital markets relatively efficient in comparison with poorly regulated external markets. Labor markets may also lack institutions training skilled labor and management, making diversified business groups, where trained personnel can be used for a variety of tasks across many group firms, a possible substitute for these institutions. 4

\subsubsection{Evidence on Groups and the Diversification Discount in Emerging Markets}

A starting point in the discussion of the validity of Hypothesis 1 is the question whether or not a diversification discount exists in emerging markets. The general answer seems to be that the diversification discount tends to be lower in environments where markets, including, but not limited to, financial markets, are less developed, in line with Hypothesis 1 . In some cases, diversified entities are even traded at a premium rather than a discount. For example, Fauver et al. (2003), who, following U.S. studies, rely on stock market data, find that the diversification discount is a feature of high income countries, with developed (financial) markets and institutions. By

\footnotetext{
versification discount'. This discount is interpreted as evidence of a causal link (corporate diversification is the cause of the reduction in shareholder wealth) in studies such as Amihud and Lev (1981); Morck et al. (1990); Lang and Stulz (1994); Berger and Ofek (1995); and Comment and Jarrell (1995). Several more recent studies have cast some doubt on the causal interpretation of the diversification discount, focusing on the endogeneity of the decision to diversify and on measurement problems of both performance and diversification; see, for example, Campa and Kedia (2002); Chevalier (2004); Villalonga (2004a) and (2004b); and Whited (2001).

${ }^{4}$ For earlier formulations of this hypothesis, see Khanna and Palepu (1999a, 2000b, and 2000c). An even earlier descriptive reasoning is due to Leff $(1976,1978)$.
} 
contrast, in low-income countries, there is no market discount - and sometimes there is even a premium - for corporate diversification. Qualitatively similar results are reported by Claessens et al. (2003), who use both stock market and accounting variables to measure the value of diversification. They find a diversification premium in the relatively poor countries in East Asia (Indonesia, the Philippines, or Thailand) and a diversification discount in the richer countries in the region (e.g., Hong Kong or Taiwan). Although both Fauver et al. (2003) and Claessens et al. (2003) refer to multisegment firms in general, not specifically to corporate groups, there is some time series evidence on business groups indicating that the relative advantage of groups declines as market institutions develop. For example, Khanna and Palepu (2000c) document the declining (stock market and accounting profitability based) group premium over a decade associated with economic reform and development of market institutions in Chile. Lee et al. (2001) observe that companies affiliated with the South Korean business groups, the chaebol, used to be traded at a premium until the early 1990s - but the premium turned into a discount starting around 1994 (see also Ferris et al., 2003). A number of other studies discussed below concur and claim that in recent years the relative performance of group affiliated companies in South Korea has not been very good, although this aggregate statistic masks considerable variation between some groups which have done very well (e.g., Samsung) and some group that have done very poorly (e.g., Daewoo).

Table 1, where unconditional risk and returns characteristics of diversified business groups around the world are displayed, suggests a more nuanced picture, which casts some doubt on the view that the benefits of diversification are higher in institutionally underdeveloped emerging markets. Although firms within certain diversified groups, for example, in Brazil, Israel, and the Philippines, outperform their non-group affiliated peers, the relative performance of firms affiliated with diversified groups cannot be easily related to economic development, to the oftencited differences in legal origins across countries (La Porta et al. 1997, 1998) or to measures of financial development. Indeed, country-specific institutional characteristics, especially those associated with financial markets, ${ }^{5}$ suggest that it is hard to find common institutional features among the countries where group firms seem to do relatively well: contract enforcement is relatively efficient in Israel and poor in the Philippines (Brazil is in between). Similarly, among the countries where group firms are characterized by low risk and low return, South Korea ranks relatively high in contract enforcement and Argentina relatively low: $]^{6}$ We conclude that diversified business groups are some-

5 See, for example, the World Bank, Doing Business data set, http://rru.worldbank.org/DoingBusiness, featuring information on the duration and cost of bankruptcy procedures as well as on the efficiency of contract enforcement.

6 Although Table 1 displays unconditional statistics, multivariate regressions generate a similarly ambiguous picture; see Khanna and Rivkin (2001) and Khanna and Yafeh (2005). 
times associated with good performance of affiliated firms, but the relation between the costs and benefits of diversification on the one hand, and economic and institutional development on the other, is probably more complex than what Hypothesis 1 suggests. The ambiguity of the results implies that in emerging markets too, there are certainly cases of diversified groups which destroy shareholder value in line with the evidence on the United States.7

Ignoring the ambiguity of the evidence in Table 1, leaving aside sample selection issues $\sqrt{8}^{8}$ and assuming that a causal interpretation can be assigned to the correlation between diversification and performance, the particular reason(s) why diversification may be optimal in (at least some) environments with relatively underdeveloped institutions is not clear. We examine several possible explanations.

\subsubsection{Evidence on Groups, Diversification and Internal Capital Markets}

Historical observations on the U.S. economy suggest that capital markets may be the underdeveloped institution driving the empirical correlation between diversification and shareholder value in different environments. There is evidence suggesting that the "diversification discount" may have been smaller in the United States in earlier periods when financial markets (more than other institutions?) were less developed..$^{9}$ This might suggest that, in such an environment, raising capital in an internal capital market of a diversified entity might have been more efficient than communicating with external potential providers of capital, primarily because of information problems.

But are internal capital markets the main reason why diversified business groups are formed in underdeveloped countries? And if so, are information problems in financial markets the crucial factor? Direct evidence on

7 An important distinction between the literature on emerging market groups and the literature on conglomerate diversification in the United States is that U.S.-based studies typically look at the relation between the diversity of an entire conglomerate and its performance, whereas in the literature on emerging markets the unit of analysis is typically an individual group firm, which resembles a âline of businessâ activity in U.S. data (see Khanna and Palepu 2000b).

8 Comparisons of group versus nongroup firms are plagued with selection issues, the most obvious one being the assumption that group affiliation is exogenous, or at least historically predetermined. Another selection problem is related to the choice of groups to list some but not all companies. This makes comparisons based on listed firms potentially biased.

9 De Long (1991), for example, argues that firms that were part of the J. P. Morgan group (had Morgan men on their boards) were traded at a premium in the early decades of the twentieth century (although causality is hard to infer from this). Moving to the 1960s, Matsusaka (1993) and Hubbard and Palia (1999) report that acquisitions of companies in industries unrelated to the bidderâs core industry were not penalized by U.S. financial markets at that time. Furthermore, Hubbard and Palia (1999) emphasize that the returns to bidders tended to be especially high when the acquired target firms were financially constrained. 
these questions is scarce. A series of studies on business groups in South Korea is indirectly supportive of the underdeveloped financial markets version of Hypothesis 1: Chang and Choi (1988), one of the earliest studies of diversified groups in South Korea, find that group-affiliated firms were more profitable than other South Korean companies in the 1980s, but several more recent studies on the South Korean chaebol report relatively poor performance of group affiliated companies in the 1990s (although some groups have continued to do very well). One interpretation of this pattern is that, as the South Korean economy became more mature and financial markets more liberalized in the 1990s, the advantage of business groups in accessing capital was gradually eroded. Nevertheless, other explanations for this pattern, not related to underdeveloped institutions (capital or other) are certainly possible: For example, South Korea faced a severe crisis in 1997-98, for which some observers blamed business groups. In the aftermath of the crisis, the government's approach toward the big business groups underwent deep changes, and this may have affected the ability of group-affiliated firms to generate profits. In addition, the fact that the founding generation of owners-managers had to turn over the keys to the second generation, typically within the family, may also have had adverse effects. It is very difficult to disentangle the impact of these different forces; the focus on one economic force or another in the existing literature seems to be somewhat arbitrary. ${ }^{10}$

More evidence on the conjecture that the performance of diversified business groups is related to internal capital markets (and imperfections in external capital markets) can be found in studies estimating investment-cash flow sensitivities for group and non-group firms (in the spirit of Fazzari et al., 1988; Hoshi et al., 1991; and Shin and Stulz 1998). Shin and Park (1999) apply this methodology to South Korean business groups, and Perotti and Gelfer (2001) to Russian financial-industrial groups (FIG), and find that individual group firms are not very sensitive to their own cash flows when

\footnotetext{
${ }^{10}$ Chang and Choi (1988) interpret their finding of superior performance of group firms as evidence that the group structure enhances efficiency through effective management and lower transaction costs, not necessarily in financial markets. They do not test this hypothesis against other possible explanations that may have made the biggest and most diversified South Korean groups relatively profitable in the 1980s. Among the studies documenting the poor performance of members of South Koreaâs business groups in the 1990s, Campbell and Keys (2002) report lower profits (but higher sales growth) for group-affiliated firms and relate this finding to inadequate corporate governance: executive turnover, they argue, is not closely related to performance. Ferris et al. (2003), who use stock market data, find that chaebol-affiliated firms currently trade at a discount and suggest that this may be due to low profits, over-investment, or inefficient cross-subsidization within the groups. Similar arguments on over-investment, typically financed by (often state-subsidized) debt, are made by Lee and Lee (2002) and by Choi and Cowing (1999). Other studies, such as Lee et al. (2000), attribute the poor performance of chaebol firms to low productive efficiency, presumably also due to overexpansion.
} 
making investment decisions; they are, however, sensitive to the cash flows of the rest of the group suggesting the existence of an internal capital market which transfers resources across firms. The welfare implications of this internal capital market are, however, ambiguous: on the positive side, a group can include a main bank (or a cash cow) and provide funding to affiliated firms too small or opaque to have easy access to outside financial markets. This should be particularly valuable when the protection of creditors and accounting standards are weak, so that arms length lending will be limited. The very limited evidence in the literature is insufficient to evaluate this conjecture: Shin and Park (1999) argue that internal capital markets within the South Korean chaebol are actually inefficient (supporting too much investment by group firms with weak investment opportunities), whereas Perotti and Gelfer (2001) do not take a stand on the efficiency of such transfers in Russia. Overall, these studies provide mixed evidence on the validity of Hypothesis 1.11

Another approach to evaluate whether diversified groups emerge in response to capital market imperfections is that of Khanna and Yafeh (2005), who test the extent to which diversified groups make up for underdeveloped financial markets by providing mutual insurance or risk sharing among group firms. They find that risk sharing is a characteristic of business groups only in a small number of emerging markets, most notably South Korea, and to a lesser extent Thailand and Taiwan. They do not find a clear relation between the extent of group diversification and the prevalence of within group risk sharing, and neither do they find any evidence that risk sharing is more common where external financial markets are less developed. This study is therefore inconsistent with Hypothesis 1 with respect to the provision of insurance in environments where the availability of state-contingent claims is very limited. ${ }^{12}$

\subsubsection{Evidence on Group Diversification for Reasons Unrelated to Capi- tal Markets}

There is some evidence supporting a version of Hypothesis 1 in which diversification is beneficial in emerging markets for reasons unrelated to financial markets. Imperfections in labor markets (both for skilled employees and for executives), limited enforcement of contracts, inadequate rule of law and other institutional deficiencies may give rise to business groups that generate these public goods for the benefit of group members. In line

\footnotetext{
${ }^{11}$ See also Samphantharak (2003) who uses a different methodology to discuss internal capital markets in Thai business groups.

${ }^{12}$ Khanna and Yafeh (2005) document also some degree of risk sharing in India through within-group transfers. For more on risk sharing in Indian business groups, see Gopalan et al. (forthcoming) who discuss group assistance to firms in distress, and Marisetty and Subrahmanyam (2006) who discuss the survival probability of group firms after going public.
} 
with this argument, Hyundai, for example, established a training center for technical personnel to be used by the entire group, as well as an applied research institute 13

Diversified groups may be efficient if they make up for missing institutions related to the process of entrepreneurship: new ventures initiated by business groups rely not only on capital infusion from the group, but often also on the group brand name and implicitly on its reputation, providing a guarantee that is scarce in emerging markets (Maurer and Sharma 2001). There is also an internal (within-group) market for talent. In this sense, some business groups are perhaps closer to private equity firms than to conglomerates. Jones (2000) makes this point in relation to British trading houses in the early twentieth century: one of the primary functions of these early groups (which, like many venture capital funds today, were often organized as partnerships) was "identifying opportunities and placing potential British investors in touch with them" (pp. 50-51). It may be possible to argue that, in India today, Tata Industries comes close to this view of a business group as a quasi-venture capitalist, albeit with longer investment horizons than typical American private equity funds (Khanna and Palepu 2005). Another Indian group, Birla, helped found and finance new firms, which were later spun-off using the entrepreneurial talent of its employees. The process of "spawning" new companies by established business groups may potentially be important in emerging markets where it is probably difficult to start de novo 14

Khanna and Palepu (1999a) use survey data to in order to try and identify sources of benefits from affiliation with a diversified group. Their analysis, which is based on intragroup confidential information, indicates that in both Chile and India group activity increased during periods following extensive liberalization and pro-market reforms, and in a way which apparently enhanced profitability. Their survey evidence suggests that this was primarily due to group advantages in product and labor (rather than capital) markets.

At present, the precise identification of the sources of group advantage remains an empirical challenge. Studies such as Khanna and Palepu (2000b) and $(2000 \mathrm{c})$, who find that in India and in Chile the relation between diversification and profitability among business groups is nonlinear (beyond a certain level diversification is associated with higher profits), can be interpreted in many ways. One way forward is perhaps to exploit variations in the nature of market imperfections across different countries. This is diffi-

\footnotetext{
${ }^{13}$ See also Khanna and Palepu (1997) on the Tata group in India, and Chang (2003a) on human resource management in South Korean business groups. Greif and Kandel (1995) discuss the underdevelopment of contract enforcement institutions in Russia in the early 1990s, which may have precipitated the emergence of financial-industrial groups.

${ }^{14}$ See Gompers et al. (2005) for a discussion of entrepreneurial spawning in the United States. In this context, diversification may be the result of within-group entrepreneurial activities rather than their cause.
} 
cult if types of market imperfections are positively correlated (e.g., where capital markets are underdeveloped, labor markets may also be so), but some interesting examples can nevertheless be found. For example, diversification in Chile, where financial markets are fairly developed and the rule of law is relatively good, is unlikely to be due to the same mix of reasons that led to the emergence of diversified groups in Suharto's Indonesia. Another related possibility is to try and disentangle various reasons for the existence of diversified groups by looking at changes in their activities and scope in response to shocks (Ghemawat and Khanna 1998). For example, a business group whose primary function is to form an internal capital market is likely to shrink or disappear in response to financial market development, whereas other groups would not. Not much research has been carried out along these lines. ${ }^{15}$

Despite the ambiguity of the results in this section, our impression is that there is some tentative evidence suggesting that, at least under some circumstances, groups can make up for underdeveloped institutions in both capital and labor markets (Khanna and Palepu 1997; Khanna 2000). Although it is difficult to draw firm conclusions from this, one possible implication might be that the profit maximizing level of diversification (and perhaps also the level of diversification which maximizes social welfare) may be higher for companies (or groups) operating in emerging markets than it is for American firms. It is not clear, however, why the business group form (rather than a fully owned conglomerate) is the most popular way to attain this level of diversification in many less developed economies. One possibility is that, from the point of view of controlling shareholders, the group structure is preferable, and only a unique historical event pre- vents the existence of business groups in the United States as well - diversified American groups were common through the mid-1930s until tax policies introduced by President Roosevelt induced either the integration of groups into conglomerates or the spin off of controlled subsidiaries (Morck 2005; we return to this historical episode below). A possible rationale for the superiority and predominance of the group form in emerging markets is that the group structure insulates the controlling shareholder from institutional investor pressure and takeovers, and bestows undisputed control and economic influence with limited capital investment. The group form may be preferred also because of legal considerations, especially in relation to corporate liability and the ability of the controlling shareholder to choose not to bailout ailing group firms (Nicodano 2003). By contrast, the conglomerate form may be more appropriate than a business group for the purpose of tax reducing income smoothing across divisions.

\footnotetext{
${ }^{15}$ Chung and Mahmood (2006), for example, document a trend of increasing diversification over the last three decades in Taiwanese business groups, which coincided with a period of deregulation. They do not provide a full explanation for this trend, and suggest that tax considerations may be involved.
} 


\subsection{Structure of Business Groups: The Extent of Vertical Inte- gration}

Limited contract enforcement, weak rule of law, corruption, and an inefficient judicial system should all lead to high transaction costs between unrelated parties. Under such circumstances, intragroup trade, within the context of long-run relationships supported by family and other social ties, may be relatively cheap and efficient. This argument is summarized in the following hypothesis:

Hypothesis 2: The presence of business groups, the extent of their vertical integration, and the volume of intragroup trade, should all be higher in environments with underdeveloped legal and judicial institutions, where contracting is costly.

\subsection{Evidence on Groups, Vertical Integration, and Contracting Costs}

Surprisingly, we are not aware of any direct evidence testing this prediction - which is similar to the Coase-Williamson arguments on the boundaries of the firm - in the context of business group structure. ${ }^{16}$ Data on the volume of intragroup trade are not readily available, and the rudimentary data on vertical integration in Table 2 are ambiguous (probably in part due to the dubious quality of the available data). On the one hand, vertical integration among groups in the Philippines is high, in line with the poor institutional infrastructure in that country. But the extent of vertical integration in relatively uncorrupt Chile is higher than in Indonesia, suggesting that there may be other explanations besides contracting costs which may account for this variation. One possibility is that vertical integration serves primarily as a means to obtain monopoly power or alleviate the double monopoly problem, rather than as a tool to overcome contracting difficulties (although the existence of contracting difficulties and opportunities to exercise monopoly power may be correlated). This view is corroborated by the CEO of the Indonesian group Astra International who described in a private interview the motivation for the vertical integration strategy of his group as driven by the pursuit of monopoly power rather than by the inadequacy of contracting institutions. The food production within the Thai CP Group has been considerably vertically integrated, but again, the stated purpose was not contracting difficulties. In addition, there seems to be considerable variation in the extent of vertical integration across groups within

\footnotetext{
${ }^{16}$ Acemoglu et al. (2005), who use firm (not group) level data, argue that, controlling for financial development and industrial structure, there is no relation between contracting costs and a vertical integration index across countries. A recent working paper by Fan et al. (2006) reports preliminary evidence of more vertical integration in Chinese provinces with weak protection of property rights in comparison with other provinces. There is no distinction in this study between vertical integration within a single firm and integration within a business group.
} 
the same country, suggesting that group and industry-specific factors play a role which is sometimes more important than country-specific institutional factors. ${ }^{17}$ The more systematic evidence on vertical integration provided by Chang (2003a) is consistent with this view: he constructs group and industry-specific measures of vertical integration for South Korea and finds it to be considerable in the largest groups and in certain industries (e.g., automobiles). He argues that vertical integration may have been an efficient strategy in the past (in line with Hypothesis 2), but it involves considerable difficulties today. ${ }^{18}$

\subsection{Structure of Business Groups: Involvement in the Finan- cial Sector}

Group involvement in banking, insurance and other aspects of the financial system may be related to transaction costs considerations similar to those driving vertical integration. A variation of Hypothesis 2 may apply to this context as well: contracting costs, institutional quality, and financial development should explain business group involvement in financial services, in addition to country-specific government regulations.

\subsubsection{Evidence on Group Involvement in Financial Services}

Historically, British multinational business groups in the early twentieth century were heavily involved in financial services over- seas, in line with Hypothesis 2 on high financial contracting costs in these environments (Jones 2000). Chilean business groups were also involved in finance prior to the liberalization and financial development of the 1980s. Large Indonesian groups typically use a group-specific financial institution, a feature that became more pronounced when their capital needs increased: Astra International, for example, was in process of expanding its automobile assembly lines in 1970s when it started acquiring banks and expanding into other financial services. In Turkey, almost all banks are group-affiliated (Yurtoglu 2000). The contemporary cross sectional evidence on group involvement in financial services and financial development provided in Table 2 suggests, however, that there is considerable variation in group involvement in financial services even among countries where financial contracting is presumably costly, perhaps because of regulatory differences.

Beyond the prevalence of group involvement in the financial sector, the

\footnotetext{
${ }^{17}$ For example, the Turkish group Eczacibasi is fully vertically integrated in its core pharmaceutical business, but other Turkish groups exhibit much less vertical integration.

${ }^{18}$ Feenstra et al. (2003) and Feenstra and Hamilton (2006) also provide evidence showing that South Korean business groups, especially the very large ones, are more vertically integrated (and more horizontally diversified) than Taiwanese groups. They propose a model with multiple competitive outcomes, rather than differences in transaction costs, to explain these differences.
} 
fragmentary existing evidence on the performance of group-affiliated financial institutions is, to some extent, consistent with the view that group involvement in this sector makes up for its underdevelopment. Maurer (1999) and Maurer and Haber (2006) emphasize the positive roles of related lending within Mexican business groups in the period 1888-1913, when contracting institutions were in their infancy. ${ }^{19}$ By contrast, La Porta et al. (2003) document the negative sides of "related lending" in contemporary Mexican groups. In the early 1980s, Chilean groups were implicated in a financial crisis and the associated failure of the first wave of privatization in that country, allegedly because of related lending. ${ }^{20}$ A conceptual difficulty in the discussion of this issue is the endogeneity of financial underdevelopment, which may actually be due to group influence; this makes the relation between business group involvement in financial services and the development of these services complex. These issues are related to the recent literature on the political economy of finance, where investor protection and financial system institutions are modeled as endogenous outcomes of political processes (see Morck et al., 2005).

\section{Ownership and Control of Business Groups}

\subsection{Pyramidal versus Other Groups}

We now turn to variation in ownership and control characteristics in business groups around the world. Perhaps the most important distinction in this category is between pyramidal and other organizational structures. This is because of the strong link in the literature, dating back to Berle and Means (1932, book 1, chapter 5), between pyramids and the expropriation of minority shareholders: in pyramidal groups there is typically a large divergence between the large shareholder's "control rights" (which are often very high) and "cash flow rights" which are typically much smaller (e.g., Arye Bebchuk et al. 2000; Bianchi et al. 2001). This, in combination with the inadequacy of some of the regulatory institutions in many emerging markets, generates an envi- ronment in which "tunneling" (the expropriation of minority shareholders) can become a common feature of the economy:

Hypothesis 3: (a) Pyramidal groups should be particularly common in countries with poor investor protection and inadequate rule of law. (b) These countries should have under-developed equity markets because investors will demand a discount when buying shares of companies affiliated with a pyramidal group. ${ }^{21}$

\footnotetext{
${ }^{19}$ See also Lamoreaux (1994) for a positive view of related lending by New England Banks in the late eighteenth and early nineteenth centuries.

${ }^{20}$ See also Chang (2003a), chapter 5, on related lending in South Korea, and Cull et al. (2006) for a discussion of conditions under which related lending has positive effects.

${ }^{21}$ Hypothesis 3 focuses on equity finance; this logic seems somewhat less applicable to debt
} 


\subsubsection{Evidence on Pyramids, Tunneling, and Financial Development}

The literature on pyramidal groups and conflicts of interest between majority and minority shareholders is discussed in great detail in Morck et al. (2005). Their reading of the evidence is consistent with Hypothesis 3 : family-controlled pyramidal business groups in countries where minority shareholders are not well protected are associated with the expropriation of small shareholders, and this adversely affects financial development ${ }^{22}$ In line with Hypothesis 3, tunneling has become the main focus of much of the recent literature on business groups: Table 3, which summarizes many of the existing studies on groups in South Korea, illustrates how the initial research interest in groups as diversified entities has been nearly completely replaced by studies of conflicts between majority and minority shareholders. In what follows we raise a number of concep- tual issues related to the literature on pyramidal groups and tunneling.

First, how many of the business groups around the world are actually vertically controlled pyramids and where are they located? Despite the centrality of this question, the answer is less clear-cut than it should be. La Porta et al. (1999), who do not focus specifically on business groups, find that widely held firms are rare outside the United States and the United Kingdom. By contrast, concentrated family ownership, often exercised through pyramids and other mechanisms that enable control in excess of cash flow rights are quite common around the world. This view is supported by Barca and Becht (2001)'s description of ownership and control of European firms (see also Faccio and Lang 2002), and by the evidence in Claessens et al. (2000) and Claessens et al. (2002) on the ownership and control of Asian firms. But even within this general framework, there seems to be considerable cross-sectional variation. Khanna and Thomas (2004) study business groups in Chile, where, they argue, pyramidal equity ties characterize less than half of all group firms. According to Barontini and Caprio (2005), unlike Claessens et al. (2002)'s description of Asian firms, a wedge between cash flow and control rights in family-dominated firms in Continental Europe is far more commonly associated with dual shares than with pyramidal structures. By contrast, Chang (2003a) argues that in South Korea pyramidal structures are common, Polsiri and Wiwattanakantang (2006) estimate (without providing precise data) that about half of the business groups in Thailand are pyramidal, and Yurtoglu (2000) discusses the prevalence of pyramids in Turkey. Some pyramidal groups can also be found in other countries such as Indonesia, Malaysia and Mexico. Part of the difficulty in mapping pyramidal groups stems from the fact that business group structures are often more complex than textbook pyramids, making a dichotomous classification of groups into pyramids and nonpyramids difficult. The

finance, which is discussed below.

${ }^{22}$ See also Almeida and Wolfenzon (forthcoming) for a theoretical discussion of these issues 
Table 3 - Studies on Business Groups in South Korea

\begin{tabular}{|c|c|c|c|c|c|}
\hline Study & $\begin{array}{l}\text { Main Argument, Sample Size, } \\
\text { Sample Period }\end{array}$ & Category & $\begin{array}{l}\text { Listed } \\
\text { Firms } \\
\text { Only? }\end{array}$ & $\begin{array}{l}\text { Groups as } \\
\text { Pyramids? }\end{array}$ & $\begin{array}{l}\text { Information } \\
\text { about } \\
\text { Families? }\end{array}$ \\
\hline $\begin{array}{l}\text { Chang and Choi } \\
\text { (1988) }\end{array}$ & $\begin{array}{l}\text { Business groups with multidivisional } \\
\text { structure show superior economic } \\
\text { performance because of reduced } \\
\text { transaction costs. } 63 \text { group affiliated } \\
\text { and } 119 \text { independent firms, } 1975-84 \text {. }\end{array}$ & $\begin{array}{l}\text { Groups as diversified } \\
\text { entities }\end{array}$ & Yes & No reference & $\begin{array}{l}\text { No specific } \\
\text { information }\end{array}$ \\
\hline $\begin{array}{l}\text { Shin and Park } \\
\text { (1999) }\end{array}$ & $\begin{array}{l}\text { Internal capital markets in the chae- } \\
\text { bol alleviate financing constraints, } \\
\text { but are associated with inefficient } \\
\text { allocation of funds. } 123 \text { group affiliat- } \\
\text { ed firms and } 194 \text { independent firms, } \\
1994-95 .\end{array}$ & $\begin{array}{l}\text { Groups as diversified } \\
\text { entities }\end{array}$ & Yes & No reference & $\begin{array}{l}\text { No specific } \\
\text { information }\end{array}$ \\
\hline $\begin{array}{l}\text { Choi and Cowing } \\
\text { (1999) }\end{array}$ & $\begin{array}{l}\text { Group firms exhibited relatively low } \\
\text { profit rates before 1989; firms affili- } \\
\text { ated with the largest groups appear } \\
\text { to have somewhat higher growth } \\
\text { rates and lower variation in profit } \\
\text { rates compared with unaffiliated } \\
\text { firms. } 91 \text { group affiliated firms and } \\
161 \text { independent firms, } 1985-93 \text {. }\end{array}$ & $\begin{array}{l}\text { Groups as diversified } \\
\text { entities }\end{array}$ & Yes & No reference & $\begin{array}{l}\text { No specific } \\
\text { information }\end{array}$ \\
\hline $\begin{array}{l}\text { Chang and Hong } \\
(2000)\end{array}$ & $\begin{array}{l}\text { Group firms benefit from group } \\
\text { membership through sharing intangi- } \\
\text { ble and financial resources with other } \\
\text { member firms. Various forms of } \\
\text { internal business transactions, such as } \\
\text { debt guarantees, equity investments } \\
\text { and internal trade are extensively } \\
\text { used for the purpose of cross-subsi- } \\
\text { dization. } 1,248 \text { companies, associated } \\
\text { with } 317 \text { business groups, } 1996 \text {. }\end{array}$ & $\begin{array}{l}\text { Groups as diversified } \\
\text { entities }\end{array}$ & $\begin{array}{l}\text { Listed or } \\
\text { statutorily } \\
\text { audited } \\
\text { companies }\end{array}$ & No reference & $\begin{array}{l}\text { Reference to } \\
\text { Samsung and } \\
\text { Hyundai }\end{array}$ \\
\hline $\begin{array}{l}\text { Bae, Kang, and } \\
\text { Kim (2002) }\end{array}$ & $\begin{array}{l}\text { When a chaebol-affiliated firm makes } \\
\text { an acquisition its stock price typically } \\
\text { falls. Minority shareholders of the } \\
\text { acquiring firm lose, but controlling } \\
\text { shareholders benefit because the } \\
\text { acquisition enhances the value of } \\
\text { other firms in the group. Consistent } \\
\text { with tunneling. } 107 \text { mergers, } 87 \\
\text { firms, 1981-97. }\end{array}$ & $\begin{array}{l}\text { Corporate } \\
\text { governance/pyramids/ } \\
\text { tunneling }\end{array}$ & $\begin{array}{l}\text { Listed on } \\
\text { the KSE }\end{array}$ & Assumed & $\begin{array}{l}\text { No specific } \\
\text { information }\end{array}$ \\
\hline $\begin{array}{l}\text { Campbell and } \\
\text { Keys (2002) }\end{array}$ & $\begin{array}{l}\text { Corporate governance problems } \\
\text { among the top chaebol may have } \\
\text { exacerbated the recent financial cri- } \\
\text { sis. } 356 \text { firms, 1993-99. }\end{array}$ & $\begin{array}{l}\text { Corporate } \\
\text { governance/pyramids } \\
\text { tunneling }\end{array}$ & $\begin{array}{l}\text { Listed on } \\
\text { the KSE }\end{array}$ & No reference & $\begin{array}{l}\text { No specific } \\
\text { information }\end{array}$ \\
\hline $\begin{array}{l}\text { Chang and Hong } \\
(2002)\end{array}$ & $\begin{array}{l}\text { Business groups play an important } \\
\text { role in developing countries by cir- } \\
\text { cumventing market inefficiencies; } \\
\text { these effects tend to be smaller in } \\
\text { large business groups, and to } \\
\text { decrease over time. } 1,666 \text { companies } \\
\text { affiliated with } 368 \text { business groups, } \\
1985-96 \text {. }\end{array}$ & $\begin{array}{l}\text { Groups as diversified } \\
\text { entities }\end{array}$ & $\begin{array}{l}\text { Listed or } \\
\text { statutorily } \\
\text { audited } \\
\text { companies }\end{array}$ & No reference & $\begin{array}{l}\text { Samsung } \\
\text { mentioned }\end{array}$ \\
\hline
\end{tabular}

Samsung group, for example, involves both vertical pyramidal control and horizontal cross shareholding, making the decision whether or not it should be considered a pyramid difficult (Kang 1997).

Second, in much of the literature, the link between pyramidal groups and the expropriation of minority shareholders is an unquestioned axiom. 
Table 3 - (continued)

\begin{tabular}{|c|c|c|c|c|c|}
\hline Study & $\begin{array}{l}\text { Main Argument, Sample Size, } \\
\text { Sample Period }\end{array}$ & Category & $\begin{array}{l}\text { Listed } \\
\text { Firms } \\
\text { Only? }\end{array}$ & $\begin{array}{l}\text { Groups as } \\
\text { Pyramids? }\end{array}$ & $\begin{array}{l}\text { Info. about } \\
\text { Families? }\end{array}$ \\
\hline Chang (2003b) & $\begin{array}{l}\text { Simultaneous nature of relationship } \\
\text { between ownership structure and } \\
\text { performance in a sample of group } \\
\text { affiliated public firms. Performance } \\
\text { determines ownership structure but } \\
\text { not vice versa: controlling share- } \\
\text { holders use insider information to } \\
\text { increase their direct and indirect } \\
\text { equity stakes in more profitable } \\
\text { firms and transfer profits to other } \\
\text { affiliates through intragroup trade. } \\
419 \text { chaebol-affiliates, 1986-96 }\end{array}$ & $\begin{array}{l}\text { Corporate } \\
\text { governance/pyramids/ } \\
\text { tunneling }\end{array}$ & Yes & $\begin{array}{l}\text { Significant } \\
\text { reference to } \\
\text { this issue }\end{array}$ & $\begin{array}{l}\text { Quite a bit of } \\
\text { reference to } \\
\text { the family } \\
\text { issue }\end{array}$ \\
\hline $\begin{array}{l}\text { Ferris, Kim, and } \\
\text { Kitsabunnarat } \\
\text { (2003) }\end{array}$ & $\begin{array}{l}\text { Chaebol-affiliated firms suffer loss } \\
\text { of value relative to nonaffiliated } \\
\text { firms. This may be due to: (1) pur- } \\
\text { suit of profit stability rather than } \\
\text { profit maximization; (2) overinvest- } \\
\text { ment in low performing industries; } \\
\text { (3) cross-subsidization of weaker } \\
\text { members of their group. } 759 \text { chae- } \\
\text { bol firm-year observations and } \\
1,316 \text { independent firm-year obser- } \\
\text { vations, 1990-95. }\end{array}$ & $\begin{array}{l}\text { Groups as diversified } \\
\text { entities }\end{array}$ & Yes & No reference & $\begin{array}{l}\text { Reference to } \\
\text { this issue; no } \\
\text { specific } \\
\text { information }\end{array}$ \\
\hline Joh (2003) & $\begin{array}{l}\text { Tunneling by controlling sharehold- } \\
\text { ers when their cash flow rights are } \\
\text { low. } 5,829 \text { firms, 1993-1997. }\end{array}$ & $\begin{array}{l}\text { Corporate } \\
\text { governance/pyramids/ } \\
\text { tunneling }\end{array}$ & $\begin{array}{l}\text { Listed or } \\
\text { otherwise } \\
\text { "registered" } \\
\text { Companies }\end{array}$ & $\begin{array}{l}\text { Reference to } \\
\text { this issue }\end{array}$ & $\begin{array}{l}\text { No specific } \\
\text { information }\end{array}$ \\
\hline $\begin{array}{l}\text { Kim and Lee } \\
\text { (2003) }\end{array}$ & $\begin{array}{l}\text { Performance during crisis is related } \\
\text { to agency problems. } 590 \text { firms, May } \\
\text { 1997-August } 1998 .\end{array}$ & $\begin{array}{l}\text { Corporate } \\
\text { governance/pyramids/ } \\
\text { tunneling }\end{array}$ & $\begin{array}{l}\text { Listed on } \\
\text { the KSE }\end{array}$ & $\begin{array}{l}\text { Reference to } \\
\text { this issue }\end{array}$ & $\begin{array}{l}\text { General ref- } \\
\text { erence }\end{array}$ \\
\hline $\begin{array}{l}\text { Baek, Kang, and } \\
\text { Park (2004) }\end{array}$ & $\begin{array}{l}\text { Change in firm value during crisis } \\
\text { is a function of firm-level differ- } \\
\text { ences in corporate governance } \\
\text { measures. } 644 \text { firms, November } \\
\text { 1997-December } 1998 \text {. }\end{array}$ & $\begin{array}{l}\text { Corporate } \\
\text { governance/pyramids/ } \\
\text { tunneling }\end{array}$ & $\begin{array}{l}\text { Listed on } \\
\text { the KSE }\end{array}$ & $\begin{array}{l}\text { Reference in } \\
\text { the model }\end{array}$ & $\begin{array}{l}\text { Control by } \\
\text { family mem- } \\
\text { bers among } \\
\text { other vars. }\end{array}$ \\
\hline $\begin{array}{l}\text { Lim and Kim } \\
(2005)\end{array}$ & $\begin{array}{l}\text { Highly leveraged groups with a } \\
\text { high proportion of nonmanufactur- } \\
\text { ing business tend to have direct } \\
\text { ownership. Larger groups with a } \\
\text { high proportion of nonvoting shares } \\
\text { tend to have pyramidal structure. } \\
\text { Groups with focused business lines } \\
\text { tend to have larger family stakes. } \\
669 \text { firms, } 1995 \text {. }\end{array}$ & $\begin{array}{l}\text { Groups as diversified } \\
\text { entities }+ \text { corporate } \\
\text { governance/pyramids/ } \\
\text { tunneling }\end{array}$ & $\begin{array}{l}\text { Listed and } \\
\text { unlisted }\end{array}$ & $\begin{array}{l}\text { Reference to } \\
\text { this issue }\end{array}$ & $\begin{array}{l}\text { Reference to } \\
\text { this issue; no } \\
\text { specific } \\
\text { information }\end{array}$ \\
\hline
\end{tabular}

Notes: This table summarizes many of the English language journal articles on the South Korean chaebol. The literature exhibits a pronounced shift in recent years from a positive (or at least mixed) view of groups as diversified entities to a clear impression that groups are undesirable. The table also illustrates some strong trends in the economics-finance profession, as reflected in the recent focus on tunneling and conflicts between controlling and minority shareholders. Features of corporate groups which were praised in some of the early studies when South Korea was doing well (e.g., centralized control) have been reinterpreted more recently as potential weaknesses, which are detrimental to small shareholders. Finally, the table demonstrates the tendency to focus on listed or quasi-listed (audited) firms (because of data constraints), the limited use of information on group structure and on familial and other possible intragroup contracts, and the absence of a dynamic perspective.

This is unwarranted: the empirical evidence on the prevalence and severity of profit tunneling from minority shareholders within pyramidal groups is far from clear-cut, although there is certainly anecdotal evidence on incidents of tunneling in Europe (Johnson et al., 2000), and more systematic evidence from pyramidal Indian business groups (Bertrand et al., 2002) 
and South Korean business groups (Bae et al., 2002; Joh 2003; Baek et al., 2006). But even these convincing studies of tunneling raise a number of unanswered questions. For example, Bertrand et al. (2002) find that Indian firms located lower within pyramidal groups are less sensitive to industryspecific shocks to their profitability than are firms located in upper levels. They interpret this result as evidence that positive shocks to firms in lower levels of the pyramid are siphoned off to firms in upper levels of the group pyramid, an activity which serves the interests of controlling shareholders, but not of minority shareholders holding an equity stake in the tunneled firms only. This interpretation is plausible for positive shocks (additional profits are taken away by the controlling shareholders), but it is less selfevident why tunneling would make firms located in low levels of the group pyramid less sensitive to negative shocks.

Bae et al. (2002) examine acquisitions of often ailing companies by other group firms within the South Korean chaebol groups and find that withingroup takeovers rarely raise the value of the bidder, but do raise the value of other group members. They also provide some examples (from the LG group, for instance) showing how such takeovers benefited controlling shareholders at the expense of minority shareholders. Very closely related methodologically is a study by Baek et al. (2006) whose focus is on private securities offerings within South Korean groups, rather than on takeovers. They find that some of these securities are offered to other group members at prices that are very far off from their true values, and document negative stock price responses to such deals. But the tunneling interpretation favored in these studies is not the only possible one; some intragroup takeovers and securities placements may also constitute efficient mutual insurance or risk sharing, as Khanna and Yafeh (2005) document for South Korea. Furthermore, Buysschaert et al. (2004) report a positive price response to withingroup equity sales in a small sample of pyramidal Belgian groups, suggesting that these transactions are not always interpreted as harmful to minority shareholders.

Moving to historical evidence from the Japanese prewar zaibatsu groups, Morck and Nakamura (2005) argue that the growth patterns of some of the Japanese prewar zaibatsu reflected the importance attributed to private benefits of control by some large shareholders. Franks et al. (2006) disagree and do not find much evidence of tunneling in the major zaibatsu groups; instead, they argue that small shareholders were happy to invest in their shares in the stock market dominated financial system of prewar Japan.

Another proxy used in the literature to measure tunneling is control premia, which are generally higher in countries where minority shareholder protection is poor (Nenova 2003; Dyck and Zingales 2004). Yet the relation between control premia, minority shareholder rights and pyramidal business groups is less than straightforward. South Korea, for example, is found to have a high control premium in both studies, yet in certain other 
countries where business groups are dominant (e.g., Indonesia) control premia are low. Furthermore, in some European countries (e.g., Austria or the Czech Republic) the value of controlling blocks is much higher than in the chaebol-dominated South Korean economy (see Dyck and Zingales 2004).

Beside the caveat that not all groups are pyramids and the fact that some of the empirical results on tunneling are open to more than one interpretation, even where groups are pyramidal in structure, reputation and other safeguards might preclude minority shareholder exploitation. Holmen and Högfeldt (2005), for example, dispute the equation of pyramids and tunneling in present-day Sweden, where there is adequate investor protection. Historically, tunneling did not seem to be a major concern for British investors in the early twentieth century, who were eager to invest money in multi- national trading groups with certain pyramidal characteristics; affiliation with one of the family-controlled British merchant houses was apparently viewed as a stamp of certification, rather than as a reason for fear of expropriation (Jones 2000, chapter 6) 23

More recent evidence in Cheung et al. (2006), who document tunneling in Hong Kong (often through "connected transactions" between related parties), suggests that tunneling is not especially common in pyramidal groups. Bennedsen and Nielsen (2006) provide evidence that in Europe dual class shares destroy more value than pyramids. In other words, not all pyramids are associated with tunneling, and tunneling is not restricted to pyramidal organizations.

Finally, much of the literature pays only scant attention to the participation constraints of investors in these pyramidal schemes. ${ }^{24}$ Why, on a routine basis, do investors continue to invest in situations where their investment is likely to be expropriated? It is, perhaps, possible to argue that naïve investors in emerging markets invest in business groups prone to tunneling because of inexperience or inadequate human capital; we find this implausible. Another possibility is that the feasible alternatives available to investors are extremely limited, although this claim probably did not apply historically to British investors in merchant houses. An explanation that we find more plausible is that group reputation for fair treatment of minority shareholders is an important consideration (see Gomes 2000 for a related theoretical model). This could be group reputation for risk sharing (or assistance to poorly performing companies) which reduces the default risk of group-affiliated companies, a feature which investors may find attractive even if they know that they are exposed to a certain risk of expropriation by controlling shareholders. A more formal mechanism is proposed by Faccio et al. (2001) who find that some groups, especially in Europe, are known to

${ }^{23}$ It is interesting to note that these pyramidal business groups did not operate within the United Kingdom, only overseas. This may support the view that business groups make up for underdeveloped institutions.

${ }^{24}$ Shleifer and Wolfenzon (2002) is a notable exception. See also Morck et al. (2000). 
pay higher dividends and thus compensate investors for the risk of expropriation. Finally, it is possible that at least some part of the alleged tunneling may in fact represent returns to some core asset, with the investing public's participation constraints being satisfied. This asset can be a socially productive one, such as some core entrepreneurial ability, or a socially detrimental lobbying capability (e.g., Faccio 2006). At present, the literature provides very few answers to these questions. ${ }^{25}$

\subsection{Family versus Nonfamily Groups}

Another dimension related to ownership and control in the taxonomy of business groups around the world has to do with role of family considerations in the presence, evolution and performance of groups:

Hypothesis 4: (a) Family-controlled groups are likely to be more common in countries with inadequate rule of law, where transactions with outsiders are costly. (b) Family considerations influence the formation, structure and performance of family-controlled groups; in some cases, groups may continue to exist for familyrelated societal reasons, even when they no longer enhance economic efficiency.

\subsubsection{Evidence on Groups and Families}

Evidence on the relation between families, the prevalence of business groups and economic institutions is provided by La Porta et al. (1999) who document higher presence of family firms (not necessarily groups) in environments where contracting is difficult. Fogel (2006), using data on the largest business groups and individual companies in over forty countries, also suggests that family ownership is more common in economies with poor institutions. One reading of these findings is that kinship and other social ties facilitate economic transactions (Granovetter 2005) and, more generally, that business groups are networks whose prevalence facilitate the creation of "trust," which makes up for incomplete contracts and imperfect rule of law. Fogel (2006), by contrast, claims that family ownership and control is the cause of economic and institutional underdevelopment ${ }^{26}$

In addition to these two international comparisons, there are a number of studies documenting the prevalence of family controlled business groups in specific countries. For Taiwan, Chung and Mahmood (2006) document considerable family equity stakes and involvement in management in 1988,

\footnotetext{
${ }^{25}$ Somewhat related to this discussion is the phenomenon of foreign investors who are reluctant to invest in Indian groups (Khanna and Palepu 2000a) or, more generally, in firms with concentrated family ownership in emerging markets with poor investor protection (Leuz et al., 2006). This could be construed as evidence of tunneling which is, for some reason, more acceptable to domestic investors than to foreigners (see also Perkins al., 2006). However, these studies do not measure the extent to which pyramidal structures in particular deter foreign investment.

${ }^{26}$ Morck et al. (2000) make a similar point.
} 
followed by a rapid decline in the 1990s, which was accompanied by an increase in the use of pyramids in order to maintain family control. ${ }^{27}$ In Singapore, Tsui-Auch (2006) suggests that about a third of the top business groups are family controlled (the rest are government linked). Family equity stakes are often above 50 percent, (without much change between 1996 and 2002), and family involvement in management is extremely high: in nine of the top ten business groups the chairman is a family member; in all but one of these firms, so is the CEO. In Malaysia, Gomez (2006) estimates that thirty-five of the top fifty business groups in 1997 were family owned, but the number has declined since the East Asian financial crisis; as in Singapore, other large groups are typically government linked. Claessens et al. (2000) dis- cuss family firms as an important feature of Asian companies more generally, and Jones (2000) regards historical British trading houses operating in Asia as well-functioning family-controlled groups.

Not only is the evidence on the prevalence of family controlled groups limited, there is also very little research on the extent to which considerations affecting family firms influence the growth and behavior of business groups. Some research on this question originates from an extensive literature within (economic) sociology, which views business groups as a family organization, whose objective is tied to the social milieu (Orrù et al., 1997). Diversification, for example, may be interpreted as a way to manage family assets - firms are merely asset holders for lineage interests (Hamilton 1997), although it is not clear from these studies why family assets cannot be divided into independent companies without the group structure. There is also no clear evidence in this literature - much of which is centered on East Asia - on whether or not family oriented groups are more prevalent in East Asia (where there is a special cultural emphasis on the family) than in other regions; there are certainly non-Asian countries with extensive family involvement in business groups: in Mexico, for instance, there is considerable family influence in all of the eight largest groups.

Beyond pure family ties, the sociology literature regards groups as network structures serving primarily social and cultural purposes, rather than seeking to achieve economic objectives. Granovetter (2005) uses the mixed evidence on the performance of group firms to suggest that considerations other than economic efficiency may be at play. The importance of noneconomic functions of business groups is reinforced, he argues, by the enormous variation in structure of business groups around the world, which is likely to reflect societal, cultural, institutional, and other norms going beyond standard economics. Factors such as inheritance customs (e.g., primogeniture or other), kinship structure, and even national ideology and pride, may all play a role in shaping corporate groups in different environments. Cultural edicts on how economic exchange should be arranged, rather than

\footnotetext{
${ }^{27}$ See also Luo and Chung (forthcoming) on family and other social ties and group perfor-
} mance in Taiwan. 
a rational response to missing markets or economic institutions, may account for differences in the structure of groups between, for example, South Korea and Taiwan (Hamilton and Feenstra 1997; Hamilton 1997).

Moving from sociology to economics, issues raised by the literature on family firms (primarily in the United States) such as succession, differences between founder controlled firms and successor-controlled ones, the importance of family control versus family management, the tendency to use debt finance and the link between all these and performance ${ }^{28}$ seem highly relevant for understanding the link between families and business groups. A recent working paper by Bertrand et al. (2004) is the first to examine these issues systematically in the context of Thai business groups dominated by ethnic Chinese families. Using elaborate data on seventy groups, they show that the group structure is related to family history and evolution, for example, to the number of male sons of the founder or to the number of brothers he had. Bertrand et al. (2004) also attempt to relate diversification and growth to family considerations, and to link group performance to intrafamily feuds. 29

The relation between family considerations and business group structure is apparently not specific to Thailand. Piramal (1998), for example, provides anecdotes describing how intergenerational considerations influence the structure of business groups in India 30 In Israel, where contracting institutions and the rule of law are considered highly developed, two tycoons, controlling two of the largest business groups, admitted recently that family considerations affected the number of companies in their groups and the appointment of senior officers (The Marker, August 17, 2006). Commonwealth of Australia (1995) emphasizes family- related issues as determinants of group structure in Indonesia, and describes family ties and inheritance customs in ethnic Chinese business groups in several other East Asian countries. There is also considerable evidence on the link between families in business group structure and performance in South Korea. Chang (2006) documents the rapidly declining equity stakes of the founding families of Hyundai and SK, whereas in other large groups family stakes were historically smaller but have remained stable. Chang and Shin (2005) show that group firms with large family stakes in South Korea do not outperform

\footnotetext{
${ }^{28}$ See Morck et al. (2005) for further discussion of this literature.

${ }^{29}$ See also Polsiri and Wiwattanakantang (2006) for information on the extensive involvement of families in the ownership and management of business groups in Thailand.

${ }^{30}$ The decision of Williamson Magor Group to acquire Union Carbide India in 1994 was apparently prompted by the Khaitan familyâs worry about its offspringâs habits. âWorried that their son . . . was spending too much time in their stable of three hundred horses, Shanti (Khaitan) persuaded her husband to make an offer.... Deepak (Khatian) needed to settle down, and she was convinced that a big company like Union Carbide would be just the right ticket.â Similarly, Kasturbhai Lalbhai, a cotton textile magnate, made four large investments the period 1929-35, of which three were designed to sustain his nephewsâ careers, and the fourth was to avoid disgracing the family name by bailing out an errant family member.
} 
other members of the same group, in contrast with what one would expect if extensive tunneling took place on behalf of the controlling families. Kim (2006) studies the relation between family ownership and total factor productivity and finds a positive relation for group firms. 31

In addition to the influence of family considerations on group structure and performance, the tendency of many groups to use debt rather than equity finance may be related to family ownership, reflecting a desire not to dilute control (Chang 2003a discusses this in the context of the South Korean chaebol). Thus, in contrast with the possible negative effects of business groups on equity markets, many groups are large borrowers and important bank clients. It is not clear, however, if this tendency is more pronounced in family-controlled groups than in stand alone family firms. ${ }^{32}$

We regard the family-firms line of research on groups as highly promising, both with respect to the prevalence of family-controlled groups in different environments, and with respect to the interaction between family considerations and group performance and efficiency. Contrasts between business groups that are single-family controlled and those that are either government controlled (in Singapore or in China) or are controlled by multiple families (e.g., LG in South Korea for at least part of its history or some joint ventures between the $\mathrm{Koc}_{s}$ and Sabanci groups in Turkey) would be particularly interesting.

${ }^{31}$ On the relation between performance of South Korean groups and the equity stakes of insiders or family members, see also Chang (2003b), Kim et al. (2004), and Lim and Kim (2005). Keister (2004) compares family and business group structure in South Korea and China, and Amsden (1989) and Kim (1997) discuss the importance of families in South Korea business groups more generally.

${ }^{32}$ On various other aspects of debt finance in business groups, see Bianco and Nicodano (2006) or Manos et al. (2004). Note also that leveraged business groups share some attributes with leveraged buyout (LBO) organizations in the United States (we are grateful to George P. Baker and Krishna Palepu for suggesting the analogy; George P. Baker and Montgomery 1994 compare LBOs with American conglomerates). As in LBOs, each business group affiliate is organized as a separate legal entity, with its own fiduciary responsibilities, its own board, and its own disclosure regime. Just like LBO associations that finance individual purchases with heavy leverage, business groups often launch new ventures with financial support from financial intermediaries. In India, for example, a typical new venture of the past few decades was launched with very little equity capital from the entrepreneur (just as in an LBO) and a lot of (equity and) debt from domestic institutional investors. There is also extensive evidence that the South Korean chaebol were extremely heavily leveraged (Clifford 1994; Chang 2003a), a feature that made them especially vulnerable during the Asian crisis of 1997-98. But the parallel between business groups in emerging markets and American LBO organizations should not be taken too far. Debt from Indian institutional investors or from government-controlled financial institutions in South Korea would hardly have the disciplining character of debt from American capital markets in the heyday of LBOs. Another striking difference is that LBO organizations in the United States were forced to liquidate their investments within a defined time period. This led to an independent measure of the value of each business (in order to sell it), and to a powerful incentive structure, quite different from that prevailing in the case of a business group in an emerging market. 
Analyzing groups from this perspective is, however, difficult for two main reasons. First, while all of the studies discussed in this section focus on the link between families and firm performance, performance might also affect the stability of the familial contract and thereby the structure of families. Bertrand et al. (2004) take a first step in addressing this issue when they treat the number of male offsprings as an endogenous outcome. Second, in many cultures, it is not at all clear that "what one sees is what one gets" with regard to the family assets. In other words, the best assets of the family might not be the publicly listed parts (Bertrand et al. 2004 and Khanna and Palepu 1999a attempt to address this issue). Furthermore, the equity contracts that are visible to the public observer and the social scientist might not be the most meaningful contracts in systems where relationship contracting predominates (Khanna and Thomas 2004).

\section{Interactions Between Business Groups and So- ciety}

\subsection{Business Groups, Politics, and Governments}

This part of the taxonomy focuses on the nature of the interaction between business groups, governments and politics. ${ }^{33}$ Because business groups have enjoyed close ties to their governments in many countries, it is not surprising that the political economy literature on groups has often viewed government-supported business groups as rent seeking "parasites." Influential papers such as Bhagwati (1982) or Krueger (1974), while not directly studying groups, have been used in support of arguments on rent-seeking through the power exercised by incumbent businesses, typically familybased business groups. Indeed, the interaction between groups and the state has received much attention over the past few decades, to the extent that an impression that all groups are deeply politically involved has been generated:

Hypothesis 5: Business groups are formed with government support, expand and diversify with government nurturing, and their performance is a function of their rent-seeking ability and opportunities.

In general, there is substantial evidence supporting the first part of the hypothesis - business groups in emerging markets are very often, though not always, formed with government support. But as the groups evolve and (some of) the countries develop, the relations between groups and governments become far more complex so that there is considerable variation in this dimension across groups and countries.

\footnotetext{
$\overline{33}$ See a related discussion in Morck et al. (2005).
} 


\subsubsection{Evidence on the Origins of Groups: The Role of Governments}

In many countries, the very appearance of the business group phenomenon was strongly influenced by government policies. The Japanese prewar zaibatsu groups emerged as a result of a government privatization program in the early 1880s, and expanded and diversified their activities in response to government contracts awarded under preferential terms (Hadley 1970). The South Korean business groups, the chaebol, enjoyed close ties to the government of General Park; the government controlled the allocation of credit and foreign currency, and the chaebol enjoyed preferential access to these and other resources (e.g., Clifford 1994; Kim 1997; Chang 2003a). The privatization policies of Prime Minister Mahathir's government in Malaysia enriched certain ethnic Malay-owned business groups dramatically (Gomez and Jomo 1999).

The Salim group in Indonesia had family ties with President Suharto and expanded, as did other Indonesian groups, with the assistance of government granted monopolies and licenses. Keister (1998 and 2004) describes how the government actively encouraged the formation of business groups in China and protected them from foreign competition. In Israel, familyowned groups emerged as an outcome of certain government economic policies (Maman 2002), and the rise of the "oligarchs" in Russia is yet another recent (and very extreme) example of the emergence of groups under the auspices of the government (Guriev and Rachinsky 2005).

Tables 4 through 7 present a comparative perspective on the origins of business groups around the world. Table 4 confirms that government support is an important factor in the formation of business groups in many environments. Nevertheless, even within countries where groups generally enjoyed government support some groups emerged with little or no government favors (e.g., Samsung, see Table 5 on prewar Japan and Table 6 on South Korea). ${ }^{34}$ Table 7 suggests that the vast majority of business groups began as family dominated corporations, often with close ties to the government 35

\subsubsection{Evidence on the Relations between Mature Groups and Govern- ments}

While in most countries groups emerged with at least some degree of government support, often in the context of development oriented mercantilist policies, the relations between mature groups and the state can vary

\footnotetext{
${ }^{34}$ Nevertheless, Kang (1997) argues that Samsungâs diversification was, at least partially, driven by an attempt to maximize rents from the governmentâs preferential interest rate policies.

35 Table 7 is based on detailed web-based and archival research by Hyunjee Kim for which we are very grateful. Examples of groups that were not family controlled even early in their development exist in Chile (Majluf et al. 1995) and in China (Keister 1998).
} 
Table 4 - The Comparative Origins of Business Groups: Historical Comparisons by Country

\begin{tabular}{|c|c|c|c|}
\hline & State-backing (general) & Privatization-related & Ethnic Policies and Family issues \\
\hline Brazil & $\begin{array}{l}\text { State protection (through tariffs and } \\
\text { non-tariff barriers and through target- } \\
\text { ing of priority sectors) benefited } \\
\text { groups, as did extensive state financ- } \\
\text { ing. In the } 1990 \text { s protection decreased } \\
\text { (although there is still some state } \\
\text { backing in the form of technology and } \\
\text { research grants and support). }\end{array}$ & & $\begin{array}{l}\text { Family ties have always been at } \\
\text { the center of groups and groups } \\
\text { today are still owned and some- } \\
\text { times run by the families that cre- } \\
\text { ated them decades ago. }\end{array}$ \\
\hline $\begin{array}{l}\text { China } \\
\text { (since the } \\
\text { 1980s) }\end{array}$ & $\begin{array}{l}\text { Government encouraged the forma- } \\
\text { tion of many business groups and pro- } \\
\text { tected them from foreign competition } \\
\text { because they were regarded as essen- } \\
\text { tial for development. However, gov- } \\
\text { ernment sentiment waxed and waned } \\
\text { depending on the fortune of business } \\
\text { groups in neighboring countries, par- } \\
\text { ticularly South Korea. In addition, the } \\
\text { People's Liberation Army has histori- } \\
\text { cally been involved in several business } \\
\text { ventures, many of which are organ- } \\
\text { ized as business groups. }\end{array}$ & & \\
\hline Chile & $\begin{array}{l}\text { Some groups benefited from the con- } \\
\text { solidation policies following the crises } \\
\text { of } 1970 \text { s and } 1980 \text { s. }\end{array}$ & $\begin{array}{l}\text { Some groups benefited } \\
\text { from privatization dur- } \\
\text { ing the Pinochet regime. }\end{array}$ & \\
\hline $\begin{array}{l}\text { Costa } \\
\text { Rica }\end{array}$ & $\begin{array}{l}\text { A limited role of the state combined } \\
\text { with a historically homogeneous dis- } \\
\text { tribution of land and coffee plants. } \\
\text { However, government protection of } \\
\text { some sectors (e.g., sugar, meat, rice) } \\
\text { led to the growth of certain groups. }\end{array}$ & & $\begin{array}{l}\text { Family groups evolved, typically as } \\
\text { a result of the success of specific } \\
\text { firms, especially in commodities. }\end{array}$ \\
\hline $\begin{array}{l}\text { Czech } \\
\text { Republic }\end{array}$ & $\begin{array}{l}\text { Industrial holding companies emerged } \\
\text { out of former Communist planning } \\
\text { units, sometimes with } 15-30 \\
\text { horizontally and vertically linked plants } \\
\text { and subsidiaries. These compa- nies } \\
\text { were voucher-privatized and } \\
\text { restructured using government subsi- } \\
\text { dies. The remaining shares were } \\
\text { bought at discount by the new man- } \\
\text { agement team and consortia of Czech } \\
\text { banks. }\end{array}$ & $\begin{array}{l}\text { Voucher privatization led } \\
\text { to the creation of large, } \\
\text { diversified invest- ment } \\
\text { funds, often indi- rectly } \\
\text { run by banks, which } \\
\text { control linked } \\
\text { enterprises. }\end{array}$ & \\
\hline India & $\begin{array}{l}\text { Favored entrepreneurs formed } \\
\text { groups during the License Raj of the } \\
1960 \text { s and } 1970 \text { s (although other } \\
\text { groups date back to the early twenti- } \\
\text { eth century). This was despite the } \\
\text { existence of de jure legislation that } \\
\text { was anti-big business (e.g., the } \\
\text { Monopolies and Restrictive Trade } \\
\text { Practices Act). }\end{array}$ & $\begin{array}{l}\text { Some entrepreneurs } \\
\text { who formed groups } \\
\text { benefited from the } \\
\text { transfer of assets for- } \\
\text { merly held by the } \\
\text { British to Indians dur- } \\
\text { ing the Independence } \\
\text { movement (de facto } \\
\text { privatization). }\end{array}$ & $\begin{array}{l}\text { Clusters of business groups formed } \\
\text { around ethnic, religious and social } \\
\text { communities, for exam- ple, the } \\
\text { Marwaris of Rajasthan formed } \\
\text { businesses in Bengal and } \\
\text { elsewhere; the Gujeratis in the } \\
\text { West, the Chettiars in the South, } \\
\text { etc. }\end{array}$ \\
\hline
\end{tabular}

(continued)

considerably. In some circumstances, groups continue to enjoy close ties with the authorities. Fisman (2001) provides convincing econometric estimates of the value of political connections enjoyed by business groups in 
Table 4 - (continued)

\begin{tabular}{|c|c|c|c|}
\hline & State-backing (general) & Privatization-related & Ethnic Policies and Family issues \\
\hline $\begin{array}{l}\text { Indonesia } \\
\text { (under } \\
\text { Suharto) }\end{array}$ & $\begin{array}{l}\text { Some groups run by members of the } \\
\text { Suharto family. Others, such as the } \\
\text { Salim group, were granted monopoly } \\
\text { over mills. Close government } \\
\text { involvement in business. State-spon- } \\
\text { sored cement and other monopolies } \\
\text { benefited groups. }\end{array}$ & $\begin{array}{l}\text { The Salim group received } \\
\text { assets seized by the } \\
\text { army. }\end{array}$ & $\begin{array}{l}\text { Suharto viewed the involvement } \\
\text { of his children in business groups } \\
\text { as a way of righting the Pribumi- } \\
\text { Chinese imbalance in the top } \\
\text { ranks of the business community } \\
\text { (although most groups are identi- } \\
\text { fied as ethnic-Chinese, including } \\
\text { the state-supported Salim group). }\end{array}$ \\
\hline Israel & $\begin{array}{l}\text { State backing of preferred groups in } \\
\text { the early decades after independence. }\end{array}$ & $\begin{array}{l}\text { Privatization-transfer } \\
\text { of some government } \\
\text { assets to families and } \\
\text { new groups in the 1990s. }\end{array}$ & \\
\hline
\end{tabular}

Government credit and protection of some groups in early postwar years

Italy (e.g., the Pesenti family who owned Pirelli). Some government-controlled groups as well.

Preferential credit and protection from Sale of assets formerly foreign competition to entrepre- neurs controlled by the following government guide- lines, Japanese and of state especially with political contacts to assets to some favored

South General Park. The government, through groups and entrepre-

Korea its control of the financial system, neurs.

(1960-90) often encouraged group diversification, mergers and consolida- tion (acquisition of ailing firms and groups), and investment in certain industries.

Preferential credit to businessmen with close ties, including members of Mahathir's family. Political parties explicitly involved in business.

Malaysia Consolidation has often been used as

(under remedy to salvage distressed firms, particularly by grouping companies under favored Malay entrepreneurs.

Until the mid 1980s, the government supported business groups by protecting many sectors through tariffs and trade restrictions, as well as by granting discretionary concessions (for example, in media, mining, and other sectors), as well direct and indirect subsidies to certain goods and industries (e.g., sugar). Groups also enjoyed monopolies, state-induced consolidation and certain protection from FDI. Since 1973, groups and conglomerates have enjoyed certain special tax incentives.
Privatization (of colonial assets and of failed government investments) buyers have political contacts and state patronage.

The privatization period (mostly 1988 to 1994 ) benefited many business groups which bought the national phone company (and was granted a monopoly for five years) and banks. Some new groups were created following the privatization of the 1990s.
Prime Minister Mahathir supports Bumiputeras (indigenous Malay) entrepreneurs in the privatization processes. Some ethnic Chinese groups operate in Malaysia and across its borders (to diversify political risks).

Family ties are crucial for business groups in Mexico. The largest industrial conglomerates in certain regions are still run by the families who started the businesses in the mid-nineteenth century, often with very strong ties to the government. 
Table 4 - (continued)

\begin{tabular}{|c|c|c|c|}
\hline & State-backing (general) & Privatization-related & Ethnic Policies and Family issues \\
\hline Nicaragua & $\begin{array}{l}\text { The government of the Somozas } \\
\text { (father and son) controlled directly a } \\
\text { large number of industries. At the } \\
\text { end of the Sandinista government } \\
\text { many firms were bankrupt and a few } \\
\text { groups acquired them, leading to } \\
\text { consolidation }\end{array}$ & & $\begin{array}{l}\text { Concentration in family groups, } \\
\text { inherited from colonial times. }\end{array}$ \\
\hline $\begin{array}{l}\text { Pakistan } \\
\text { (starting } \\
\text { around } \\
1960 \text { ) }\end{array}$ & $\begin{array}{l}\text { Foreign exchange licenses given pri- } \\
\text { marily to rich families. Combined } \\
\text { with restrictions on imports. }\end{array}$ & & \\
\hline Russia & $\begin{array}{l}\text { Some (limited) government support of } \\
\text { industry-led FIGs which evolved with } \\
\text { the collapse of Communism; much } \\
\text { more support of the bank-led FIGs } \\
\text { which enjoy (enjoyed?) political clout, } \\
\text { lobbying power for various privileges } \\
\text { (e.g., restrictions on for- eign } \\
\text { investors), and influence the media. }\end{array}$ & $\begin{array}{l}\text { Industry-led financial- } \\
\text { industrial groups (FIGs) } \\
\text { emerged early in the pri- } \\
\text { vatization process. Bank- } \\
\text { led FIGs emerged later, in } \\
\text { relation to auctions } \\
\text { initiated by President } \\
\text { Yeltsin favoring (some) } \\
\text { buyers; state assets sold } \\
\text { at low prices to } \\
\text { "Oligarchs." }\end{array}$ & \\
\hline Singapore & $\begin{array}{l}\text { Government-linked business groups } \\
\text { established in the } 1960 \text { s and } 1970 \text { s in } \\
\text { order to make economic investments } \\
\text { jointly with private investors. }\end{array}$ & & $\begin{array}{l}\text { Ethnic Chinese, who felt threat- } \\
\text { ened by the government formed } \\
\text { private, family controlled groups, } \\
\text { diversifying across industries and } \\
\text { borders to reduce risk. }\end{array}$ \\
\hline $\begin{array}{l}\text { South } \\
\text { Africa }\end{array}$ & & & $\begin{array}{l}\text { During Apartheid, major groups } \\
\text { were associated with the whites; } \\
\text { In the postapartheid period, the } \\
\text { adoption of Black Economic } \\
\text { Empowerment policies induced a } \\
\text { transfer of assets from whites to } \\
\text { blacks, and the formation of con- } \\
\text { glomerates by select black entre- } \\
\text { preneurs, some of whom had } \\
\text { political contacts to the ANC. }\end{array}$ \\
\hline Taiwan & $\begin{array}{l}\text { Not much government support and } \\
\text { encouragement; family groups formed } \\
\text { endogenously (but benefited from } \\
\text { certain tax advantages starting in the } \\
\text { 1960s). }\end{array}$ & & \\
\hline Thailand & $\begin{array}{l}\text { Some groups originated in the 1940s; } \\
\text { politicians and military officers often } \\
\text { involved in business groups; restricted } \\
\text { competition in many sectors favors } \\
\text { groups. }\end{array}$ & & $\begin{array}{l}\text { Groups are often dominated by } \\
\text { ethnic Chinese, some of whom } \\
\text { operate in neighboring countries } \\
\text { as well. }\end{array}$ \\
\hline
\end{tabular}


Table 4 - (continued)

\begin{tabular}{|c|c|c|c|}
\hline & State-backing (general) & Privatization-related & Ethnic Policies and Family issues \\
\hline Turkey & $\begin{array}{l}\text { Between } 1923 \text { and } 1980 \text { some groups } \\
\text { were supported through preferential } \\
\text { input prices, low-cost credits, tax } \\
\text { rebates, foreign exchange licenses, } \\
\text { import licenses, government con- } \\
\text { tracts, as well as through export-spe- } \\
\text { cific measures allowing business groups } \\
\text { to establish large export com- panies in } \\
\text { the1980s. The government also } \\
\text { encouraged diversification and } \\
\text { internationalization of business groups } \\
\text { via various economic incentives. (But } \\
\text { several group-owned banks were } \\
\text { taken over by the government after } \\
\text { the bank crisis in 2001.) }\end{array}$ & $\begin{array}{l}\text { Relatively larger busi- } \\
\text { ness groups are the } \\
\text { favored participants in } \\
\text { the privatization of state } \\
\text { owned enterprises, espe- } \\
\text { cially those with strong } \\
\text { political ties. Smaller } \\
\text { family groups participate } \\
\text { in the privatization } \\
\text { efforts of smaller state } \\
\text { assets. }\end{array}$ & $\begin{array}{l}\text { The nineteenth century business } \\
\text { elite was mostly composed of eth- } \\
\text { nic minorities and foreign } \\
\text { investors. With the founding of the } \\
\text { new Turkish Republic in } \\
\text { 1923, the economic agenda } \\
\text { stressed creating an indigenous } \\
\text { business class: bureaucrats, mer- } \\
\text { chants, and professionals were } \\
\text { encouraged to become entrepre- } \\
\text { neurs. }\end{array}$ \\
\hline $\begin{array}{l}\text { Nine- } \\
\text { teenth } \\
\text { Century } \\
\text { Japan }\end{array}$ & $\begin{array}{l}\text { Some "political merchants" received } \\
\text { state credit and grants. Ailing govern- } \\
\text { ment businesses privatized and sold to } \\
\text { the zaibatsu. Government contracts } \\
\text { encouraged group growth around } \\
\text { major wars. }\end{array}$ & & \\
\hline
\end{tabular}

Indonesia during the Suharto regime (see also Leuz and Oberholzer-Gee 2006). Gomez (2006, Appendix table 6.1) delineates the extensive and close ties between business groups and the government in Malaysia (see also Johnson and Mitton 2003). In India, some business groups were able to receive favorable treatment from the "License Raj" in certain periods (Tripathi 2004). There are yet more extreme examples of symbiosis between business groups and the government: each of the two major Japanese zaibatsu, Mitsui and Mitsubishi, virtually controlled one of the major parties in the Japanese parliament in the 1910s.

More recently, some owners of South Korean chaebol seemed to entertain political aspirations (e.g., Chairman Chung of Hyundai ran for president in 1993), a Turkish business group has launched a political party, allegedly so that their representation in government can confer political immunity on them (Mango 2004), and in Malaysia some business groups are centered on political parties (e.g., the Malay political party UMNO or the Chinese political party MCA; see Gomez and Jomo 1999 and some discussion in Commonwealth of Australia 1995). Bunkanwanicha and Wiwattanakantang (2005) describe Thai business tycoons who enter politics in order to win various government concessions, and in Singapore there are still some fully government controlled business groups (Temasek, for example, which controls Singapore Airlines).

But governments and business groups do not always operate symbiotically. First, there are a number of historical examples when governments harmed, rather than assisted, business groups. This has happened both in times of wrenching societal transformation - e.g., when the Chinese Communist Party took power in 1949 - and in an ongoing sense when groups 
Table 5 - The Comparative Origins of Business: Group-Specific Origins in Nineteenth Century Japan

\begin{tabular}{|c|c|c|}
\hline & Origin & Growth and Relations with the State \\
\hline Mitsui* & $\begin{array}{l}\text { Dates back to } 1673 \text { (dry goods); "political } \\
\text { merchants"1 who provided financial services } \\
\text { to the Tokugawa regime since the late seven- } \\
\text { teenth century. }\end{array}$ & $\begin{array}{l}\text { Historically close ties with various governments. } \\
\text { Growth and diversification through acquisitions and } \\
\text { through establishment of new businesses, in part } \\
\text { through government privatization and contracts. }\end{array}$ \\
\hline Mitsubishi* & $\begin{array}{l}\text { Founded by a former Samurai after the Meiji } \\
\text { Restoration. }\end{array}$ & $\begin{array}{l}\text { Initial investment in shipping enjoyed government } \\
\text { protection, subsidies, loans etc. Subsequent growth } \\
\text { and diversification patterns broadly similar to } \\
\text { Mitsui's. }\end{array}$ \\
\hline Sumitomo* & $\begin{array}{l}\text { Dates back to the late sixteenth century, with } \\
\text { ties to the Tokugawa regime. }\end{array}$ & $\begin{array}{l}\text { Diversified from mining into trading, finance and } \\
\text { industry. Again, diversification and growth through } \\
\text { both acquisitions and through the establishment of } \\
\text { new businesses, with government support. }\end{array}$ \\
\hline Yasuda* & $\begin{array}{l}\text { "Political merchants" from the Meiji } \\
\text { Restoration period. Mainly provided finan- } \\
\text { cial services (including the establishment of } \\
\text { the third national bank in 1876). }\end{array}$ & $\begin{array}{l}\text { Less diversified than the other big groups, more } \\
\text { focused on banking and finance. Again, both acqui- } \\
\text { sitions and new businesses as mechanisms of } \\
\text { growth. }\end{array}$ \\
\hline Asano & Around 1870; no previous political ties. & $\begin{array}{l}\text { Initial fortune out of various investments. Growth } \\
\text { through cooperation with a separate financial insti- } \\
\text { tution. }\end{array}$ \\
\hline Fujita & $\begin{array}{l}\text { Origin: supplier of goods and engineering } \\
\text { works to the new government (with contacts } \\
\text { to major figures in the Meiji government). }\end{array}$ & $\begin{array}{l}\text { An internal family feud led to the dissolution of this } \\
\text { group and its reorganization as the Kuhara zaibatsu } \\
\text { in } 1905 \text {. }\end{array}$ \\
\hline Furukawa & $\begin{array}{l}\text { Formed in } 1874 \text {, related to old wealth from } \\
\text { the Ono family. }\end{array}$ & $\begin{array}{l}\text { Mostly in mining and utilities, e.g., established the first } \\
\text { hydroelectric power plant in } 1890 \text {. Characterized by } \\
\text { more vertical integration (e.g., in copper extrac- tion } \\
\text { and production) than diversification. }\end{array}$ \\
\hline Okura & $\begin{array}{l}\text { Merchant (groceries) before the Meiji } \\
\text { Restoration; converted into gun production } \\
\text { in the } 1860 \text { s and then into overseas trading } \\
\text { starting } 1873 \text {. }\end{array}$ & $\begin{array}{l}\text { Growth mainly through acquisitions. Despite sub- } \\
\text { stantial operations overseas, government contracts } \\
\text { remained a major source of income. }\end{array}$ \\
\hline
\end{tabular}

[1] This refers to the Japanese term seisho which is defined by Morikawa (1992, p. 3) as "traders and financiers who used their ties to powerful political figures to obtain government favors, enabling them to earn substantial profit in return for providing goods and services to the state. Government patronage took the form of subsidies, grants and monopolies or special privileges, favorable credit arrangements, and sales of state enterprises at nominal prices."

$\left(^{*}\right)$ denotes the big four zaibatsu groups

Source: Morikawa (1992).

struggled in the face of an inimical state - e.g., India's socialist government in the few decades following Indian independence; indeed Khanna and Palepu (2005) point out that the turnover in leading Indian groups across the past sixty years is far too high to be consistent with entrenchment and close group-government ties. In Pinochet's Chile, after the fall of Allende's Socialist government in 1973, pro-free-market and antiownership concentration policies were adopted, which were sometimes antibusiness groups. In South Korea, Siegel (2006) shows that political regime changes lead to differences in the particular firms that receive government favors according to social ties between the office holder and senior managers. Furthermore, even within the same group, different affiliates may either be favored or 
Table 6 - The Comparative Origins of Business Groups: Group-Specific Origins in Present-Day South Korea

\begin{tabular}{|c|c|c|}
\hline & Origin & Growth and Relations with the State \\
\hline Hyundai & $\begin{array}{l}\text { Mr. Chung (the founder) started by } \\
\text { providing mechanical services to } \\
\text { the American army; later estab- } \\
\text { lished contacts with the Syngman } \\
\text { Rhee regime. }\end{array}$ & $\begin{array}{l}\text { Together with Daewoo, one of General Park's favored groups } \\
\text { in the } 1970 \text { s, when Hyundai cooperated with the government's } \\
\text { policy of investment in heavy and chemical industries. } \\
\text { Obtained licenses and government finance as well as preferen- } \\
\text { tial tax treatment and protection from imports. Growth } \\
\text { through both acquisitions and entry into new industries. } \\
\text { Allegedly, Hyundai and other big groups used government } \\
\text { contacts to improve their competitive positions, occasionally } \\
\text { by acquiring assets of ailing groups and by winning major gov- } \\
\text { ernment contracts. Mr. Chung was General Park's "informal } \\
\text { construction minister" and a personal friend. }\end{array}$ \\
\hline Daewoo & $\begin{array}{l}\text { Mr. Kim (the founder) was the son } \\
\text { of General Park's teacher. Group } \\
\text { established in } 1967 .\end{array}$ & $\begin{array}{l}\text { Close relations with the government, which transferred to } \\
\text { Daewoo the Okpo shipyard and some assets in the auto } \\
\text { industry previously owned by GM. Government-induced } \\
\text { investments in heavy industry. Expansion mainly through } \\
\text { acquisitions. Strong international orientation (overseas invest- } \\
\text { ments). }\end{array}$ \\
\hline Samsung & $\begin{array}{l}\text { Mr. Lee (the founder) established } \\
\text { the company in } 1938 \text {, using some } \\
\text { inherited wealth. Acquisition of } \\
\text { assets left by the Japanese in } 1945 .\end{array}$ & $\begin{array}{l}\text { Samsung was relatively large already in the 1950s; made polit- } \\
\text { ical "donations" and established contacts in government. But } \\
\text { relations with the state were turbulent in comparison with the } \\
\text { other major groups: General Park forced Samsung to } \\
\text { "donate" some of its assets soon after taking power, and for a } \\
\text { while the group was virtually excluded from most government } \\
\text { contracts. Instead, growth fostered through cooperation with } \\
\text { foreign firms; relative focus on electronics. Growth and diver- } \\
\text { sification in 1960s through both acquisitions and establish- } \\
\text { ment of new businesses. }\end{array}$ \\
\hline LG & $\begin{array}{l}\text { Founded as a trading company in } \\
1947 .\end{array}$ & $\begin{array}{l}\text { Growth mostly in electronics and chemicals; benefited from } \\
\text { government development plans in the 1960s; related diversifi- } \\
\text { cation strategy. }\end{array}$ \\
\hline SK & $\begin{array}{l}\text { Founded in 1957; close ties with } \\
\text { the government since inception. }\end{array}$ & $\begin{array}{l}\text { Much of its growth driven by acquisition of privatized state } \\
\text { assets (including property left by the Japanese), through close } \\
\text { ties to the government, including the marriage of the founder's } \\
\text { son to the daughter of President Roh. }\end{array}$ \\
\hline
\end{tabular}

Source: Clifford (1994) and Chang (2003a).).

punished depending on their CEO or Chairman's social ties to the current political regime. In the United States, Morck (2005) and Morck and Yeung (2005) describe how President Roosevelt took policy measures against business groups (see Table 4 for other examples).

Even where governments were not hostile toward business groups, the relationship between them often changed over time, as groups became stronger and more independent. This seems to have been the case in Japan in the 1930s (Franks et al., 2006) and in South Korea starting in the 1980s (Amsden 1989; Clifford 1994; Kim 1997; Chang 2003a; Lee et al. 2002), where the expression the "Republic of Samsung" is sometimes used. In post-1997 South Korea, the government has actively tried to weaken the chaebol albeit with limited success in view of their power and influence (although Borensztein and Lee, 2002 provide evidence that group firms lost their preferential access to capital following the crisis). The overall conclusion from this evidence is that as business groups accumulate political and economic 
Table 7 - The Comparative Origins Of Business Groups: Initial Control Structure Of Business Groups

\begin{tabular}{ccc}
\hline \hline & Family & Others \\
\hline Indonesia & Nearly Complete & $\begin{array}{c}\text { Some state involvement } \\
\text { Malaysia }\end{array}$ \\
High (90+ percent) & $\begin{array}{c}\text { State involvement and } \\
\text { some foreign investment }\end{array}$ \\
Thailand & High (80 percent) & Some state involvement \\
Turkey & Nearly Complete & N/A \\
Mexico & High (90 percent) & Some state involvement \\
\hline \hline
\end{tabular}

Source: The table is based on detailed archival, web-based, and interviews by Hyunjee Kim. ISI Emerging Markets Database, One Source Database, Hooverâs Database, Datamonitor Company Report, websites and annual reports. Data refer to the largest firms within the largest groups in each country. Family control is defined as having the founding family holding at least 20 percent of the equity during the first decade after the group was founded. In Malaysia, for example, over 90 percent of the group firms examined satisfy this criterion.

influence, the nature of their relations with government tends to change from government protégés to a strong lobby with often captured regulators (in line with phenomenon of "entrenchment" emphasized by Morck et al., 2005) or to a sector that loses favor with the authorities because of its excessive influence 36

\subsubsection{The Welfare Implications of Close Ties between Groups and Gov- ernments}

The prevailing assumption in much of the literature is that government support of groups is socially harmful. Despite the negative implications of government favors of the type described above, there may also be a bright side: business groups may have helped governments orchestrate a "big push" in several sectors simultaneously (arguably in prewar Japan, see, for example, Ohkawa and Rosovsky 1973). In other cases, governmental favoritism towards business groups controlled by an ethnic minority may have helped preserve social equilibrium, as in Malaysia. The appropriate counterfactual against which this government policy should be judged may well be race riots and chaos. Similar government-directed transfers are currently being attempted in South Africa, under the label of Black Economic Empowerment, with groups forming around emergent successful black entrepreneurs in the post- Apartheid regime - again, the overall economic

\footnotetext{
${ }^{36}$ The changing relations between groups and government may be related also to changes in the ownership structure of business groups over time. For example, in Indonesia or Mexico, foreigners often hold very significant equity stakes in business groups firmsâmany group firms among the largest business groups in Indonesia, Mexico, and South Africa have foreign ownership of 20 percent or more. This may affect the nature of ties between groups and politicians.
} 
value of such a policy is not easy to gauge ${ }^{37}$

Social welfare might be enhanced by group government liaisons if, for instance, the relation between groups and governments supports tax collection and fiscal policy. Do governments favor groups because it is easy to collect taxes from them? If so, this would be reminiscent of medieval rulers who partitioned their territories into fiefdoms con- trolled by quasiindependent lords who could rule them as they saw fit as long as they paid their taxes to the government. This issue has rarely been addressed in the literature. Morikawa (1992) notes that taxes collected from the Japanese $z a$ ibatsu during World War II were substantial. By contrast, Morck (2005) describes how the U.S. tax authorities felt that collecting taxes from business groups was especially difficult because of tunneling, and so supported (perhaps even initiated) President Roosevelt's attack on business groups. Chang (2003a) suggests that South Korean groups shift funds so as to reduce their tax liability. Desai et al. (forthcoming) argue that inefficient corporate governance structures associated with the expropriation of the rights of minority shareholders are likely to be associated also with tax evasion (expropriation of the government's rights). Clearly, more systematic evidence on this issue from various countries would be of interest.

Analytically, it might not always be sensible to study just the interaction between the private sector and the government, without considering additional constituencies. For example, Musacchio (2004) argues that the rise of business groups (and concentrated ownership) in Brazil coincided with the rising power of organized labor, with the government playing only a background role. Huang (2003) discusses the general suppression of the indigenous private sector in China. This analysis, along with Keister's (2004) study of the forced formation of business groups in China, suggests that the government favors business groups formed by the state but discriminates against business groups formed by private entities.

In some countries, the government might itself be in transition, affecting the formation and evolution of business groups. In Czechoslovakia, for example, newly formed groups reflected new networks of companies, as power shifted from the Communist government to the regime that replaced it (McDermott 2002; see also Stark, 1996 on post-Communist corporate networks in Hungary) ${ }^{38}$

\footnotetext{
${ }^{37}$ The relevant legislation is the broad-based Black Economic Empowerment Bill, no. 53, of 2003.

${ }^{38}$ Somewhat related is a historical anecdote from early twentieth century British India, when the Birla group supported and financed indigenous Indian businesses and entrepreneurs as an alternative to the British-dominated business scene (Piramal 1998; Tripathi 2004).
} 


\subsubsection{Evidence on the Political Ability of Groups to Shape their Environ- ment}

Can business groups use their political clout to shape their business environment? This central question has no systematic answer in the existing literature. Historically, groups have often invested in market supporting infrastructure and launched new industries - the Japanese zaibatsu are a good example. There are also claims that business groups in Mexico exerted influence in favor of free trade with the United States from which the groups were hoping to benefit. Kim (1997) argues that the South Korean groups lobbied for liberalization in the 1980s, and Chari and Gupta (2006) show that in India industries with high presence of group-affiliated firms were more likely to be associated with liberalization of foreign entry in the early 1990s than industries dominated by state owned firms. ${ }^{39}$ By contrast, groups may resist certain political reforms, improvements in minority shareholder protection or antitrust legislation - this seems to be the case in South Korea in recent years (Chang 2003a). Morck et al. (2005) argue that "entrenchment" through political clout is often used by business groups to restrict entry and competition. Rajan and Zingales (2003) also express concern about the ability of business incumbents (not specifically groups) to curtail competition and free financial markets. The ability of groups to shape their environment may also be related to attempts by business groups in many countries to gain influence on the media (Karademir and Danisman, 2006 describe this for the case of Turkey).

Two conclusions emerge from this discussion. First, political economy explanations for the formation and effectiveness of groups, beyond the traditional focus on government favors, should receive more attention. Second, it might be fruitful to view the relations between groups and the state as the equilibrium outcome of a game, in the spirit of work by Aoki (2001) and Greif (2006). These games are typically complex, and their application to a particular context is not always straightforward. Nevertheless, conceptually, the result of such a government business group game might well be rent seeking and cohabitation, but it might also be an uneasy coexistence, quite distinct from the outcome of groups currying favor with the state ${ }^{40}$

\subsection{Business Groups and Monopoly Power}

There are good theoretical reasons to suspect that business groups may wield considerable market power. They may, under some circumstances, drive their rivals out of markets, or prevent entry, due to their "deep pock-

\footnotetext{
${ }^{39}$ This is in some contradiction to Tripathi (2004), who argues that the Bombay Club (of Indian industrialists) lobbied for restricted entry of foreign multinationals.

${ }^{40}$ It would be interesting to model the relation between ties with the government and the business group structure, in contrast with politically connected firms operating in one industry.
} 
ets," "first mover advantage," and ties to the government. "Multimarket contact" (Bernheim and Whinston, 1990) between diversified business groups competing with each other repeatedly in many sectors may facilitate collusion. And business groups may bundle together different group products in order to extract more rents from distributors and ultimate buyers. It is not clear, however, if these considerations are the rationale behind the formation of business groups.

Hypothesis 6: (a) Business group formation should involve horizontal mergers, vertical foreclosure, entry deterrence, and other mechanisms designed to increase market power. (b) Monopoly power should be reflected in high profit rates. (c) Group presence should be especially pronounced in environments where monopoly rents can be extracted such as industries and countries with trade barriers and weak antitrust enforcement.

\subsubsection{Evidence on Business Groups and Monopoly Power}

The theoretical conjectures associating business groups with monopoly power enjoyed popular support in the past, albeit without rigorous empirical tests. The view that business groups harm competition dates back to the Great Depression in the United States. Morck (2005) argues that President Roosevelt sought to dissolve America's groups (by taxing intercorporate dividends) partly on these grounds. One of the primary objectives of the postwar American occupation reforms in Japan was the dissolution of the prewar zaibatsu, which was driven by strong views on their anticompetitive effects and the resulting social tension that may have contributed to the rise of militarism in Japan (Hadley 1970; Yafeh 1995). Ginette KurganVan Hentenryk (1997) suggests the Belgian business groups facilitated the cartelization of the Belgian coal industry in the interwar period.

Nevertheless, despite the plausibility of arguments on groups and monopoly power, the literature on the industrial organization effects of business groups has not developed much. The theoretical relation between group affiliation and entry deterrence is explored formally in an interesting recent study by Cestone and Fumagalli (2005). They show that internal capital markets are not always advantageous to group affiliated firms when they try to deter entry; under certain conditions they may actually be "softer" than stand-alone firms. ${ }^{41}$ There seems to be scope for many more theoretical analyses of groups and industrial organization.

Empirical evidence on the hypothesis that business groups restrict competition is surprisingly scarce. Casual observation suggests that not all groups enjoy high profit rates and monopoly rents (Table 1). The few studies directly testing the monopoly power of business groups use not very re-

${ }^{41}$ See also Faure-Grimaud and Inderst (2005) who discuss related issues in the context of conglomerates with internal capital markets. Feenstra and Hamilton (2006) also discuss monopoly power of business groups in a different context. 
cent data from developed economies: Encaoua and Jacquemin (1982) investigate French industrial groups and find little evidence of their having any market power (although the econometric techniques used in empirical industrial organization have evolved significantly since then); Weinstein and Yafeh (1995) argue that (in the 1980s) Japan's bank-centered groups competed aggressively against each other rather than colluded. Although there are no similar studies for emerging markets, there are occasional descriptions of the intense rivalry between the South Korean chaebol. These are not formally substantiated, and even if true, do not necessarily preclude anticompetitive entry deterrence. Other anecdotes refer to collusion across ethnic Chinese business groups in East Asia (Commonwealth of Australia 1995). Mobarak and Purbasari (2005) provide more systematic evidence they show how politically connected Indonesian business groups used their influence during Suharto's reign to win exclusive import licenses conferring protection from imports, market power, and competitive advantage relative to their rivals, leading to increased concentration. There is also fairly systematic evidence on changes in the relative size and rankings of business groups over time, which could be interpreted as evidence of competition or erosion of monopoly power - the list of top ten business groups has changed dramatically over the past three decades in India and Taiwan, but has remained very stable in South Korea and Thailand ${ }^{42}$ It is not clear, however, why groups in some countries wield less power to restrict entry than groups in other countries. Overall it is surprising that no attempts have been made to use modern NEIO (New Empirical Industrial Organization) techniques to assess the market power of business groups in emerging markets.

\section{Directions for Future Research}

This final section outlines general directions for future research in view of what we believe we know, and what we would like to know, about business groups in emerging markets.

\subsection{Origin and Formation of Business Groups}

The formation of business groups remains largely unexplained. Because of this lacuna, selection effects may render comparisons of groups and nongroup firms invalid. We view this as an important direction for both theoretical and empirical future research.

\footnotetext{
42 In India, only three of the top ten groups in 1969 were included in the list of top ten groups in 1997. Taiwan is similar to India in this respect: only three of the top ten groups of 1973 appear on the list for 2002. By contrast, in South Korea, six of the top groups in 1972 were among the top ten groups in 1996, and in Thailand too, six of the top ten groups in 1979 appeared on the list of top ten business groups in 1997 (Khanna and Palepu 2005; Chung and Mahmood 2006; Chang 2003a; Polsiri and Wiwattanakantang 2006, respectively).
} 
The existing theoretical literature on the formation of business groups consists of no more than a handful of models. Kali (1999) studies the endogenous formation of business networks in response to limited contract enforcement by the legal system; Maurer and Sharma (2001) also focus on imperfect property rights. Ghatak and Kali (2001) and Kali (2003) emphasize imperfect information in capital markets as another possible motive. Almeida and Wolfenzon (forthcoming) offer a theoretical explanation for the formation of pyramidal groups which is based on the ability of controlling shareholders to access the cash flows of all group firms so as not to rely on underdeveloped external financial markets. A particularly intriguing theoretical direction (also related to underdeveloped financial markets) would relate the formation of groups to risk attitudes: are groups a mutual insurance arrangement attracting risk-averse economic agents? Kim (2004) is the only existing model along these lines. ${ }^{43}$

Existing empirical studies of the formation of groups are often based on small data sets and employ empirical techniques that are not fully convincing. For example, Chung $(2001,2006)$ examines the origin and evolution of groups in Taiwan, distinguishing between reasons related to market forces, culture, and societal institutions, but the relative empirical importance of these factors is hard to disentangle. Tsui-Auch (2005) documents a tendency among ethnic Chinese entrepreneurs in Singapore to form diversified business organizations (in comparison with ethnic Indian entrepreneurs), and attributes this interesting observation to the cultural heterogeneity of the Chinese community. The empirical support for this claim, however, is suspect because of other systematic differences in the background of Chinese and Indian entrepreneurs in Singapore. More sophisticated empirical analyses of the differential origins of business groups are likely to be valuable.

Somewhat related conceptually is the idea to use within-country variation in the structure and development of business groups to draw some conclusions on the forces that lead to their formation. For example, it appears that the Chinese government pursued liberalization primarily in regions where it was weak (the south), and not in the Northeast (e.g., Beijing) where the Communist Party had its pre-1949 stronghold. Is it the case then that state-sponsored groups created by fiat are developing primarily in the Northeast? Variation in group presence across Indian provinces might shed light on the relation between the formation of business groups and issues related to ethnic identity and perhaps also to "trust." For example, is it possible to map the presence of certain ethnic groups in certain regions (e.g., Marwaris in Rajasthan and, by migration, in Bengal; Chettiars in the south) to the formation and development of groups along similar ethnic lines? Indian business groups offer an opportunity to take advantage of the variation

${ }^{43}$ The empirical evidence in Munshi and Rosenzweig (2005) on informal mutual insurance institutions in India, and in Abramitzky (2005) on the Israeli Kibbutz may offer some useful related insights. 
over time in the processes that led to the formation - some groups, like the Tatas and Birlas were created by indigenous entrepreneurs during the time of the British Empire; a second wave, like the Goenkas and the Khaitans, were the product of the post-independence (1947) transfer of assets from the British to Indians; a third set originated during India's "License Raj" of the 1960s and 1970s. Can these different circumstances be related to group structure?

\subsection{Evolution and Dynamics of Business Groups}

Historical and dynamic (over a long period of time) perspectives of business groups can enrich our understanding of this institution in several ways. First, it would be interesting to compare the validity of cross-sectional explanations for the ubiquity and performance of business groups with timeseries based perspectives (Jones and Khanna 2006) - do groups evolve in a fashion that is consistent with missing institutions, risk sharing, tunneling, use of a scarce resource, etc.? The Japanese prewar zaibatsu provide an obvious opportunity to carry out such an analysis because of the wealth of information about their activities and development, providing over five decades of data $\sqrt{44}$ Another possibility is the shorter, but more recent history of the South Korean chaebol. ${ }^{45}$ There are other interesting examples: Maurer and Sharma (2001) study the evolution of nineteenth century Mexican business groups (which, in their view, was a response to limited contract enforcement); Khanna and Palepu (2005) study the evolution of business groups in India (which, they argue, fits the view of groups as a substitute for underdeveloped institutions; see also Jones 2000 on historical British groups); and Aganin and Volpin (2005) study the evolution of Italian groups (focusing on investor protection and political issues).

Many more historical studies with explicit hypotheses in mind, especially with competing hypotheses whose testable implications can be contrasted in time-series data, could shed further light on the evolution of groups, on path dependence (ways in which"history matters"), and on the raison d'être of group formation and development.

\footnotetext{
${ }^{44}$ Morikawa (1992) is the most detailed English-language study of these groups with a plethora of information on their origins, evolving relations with the government, growth and diversification patterns, controlling families, human resource management, and more. He tends to interpret the zaibatsu growth and diversification history in a Chandlerian tradition of efficient management and use of internal resources. The evidence he provides, however, is not really set up in a way that enables testing competing hypotheses about the reasons for the existence and growth of these groups

${ }^{45}$ Chang (2003a) argues that, much like the Japanese zaibatsu in the late nineteenth century, South Korea's business groups developed under the auspices of a development-oriented government, but gradually became independent and pursued a growth strategy that reflected their resources and competitive advantages.
} 


\subsection{Longevity of Business Groups}

Although there is no systematic evidence on the question whether or not the longevity of group affiliates exceeds that of otherwise comparable, unaffiliated firms, in many countries, very long-lived groups can be found. In some cases, groups have survived, without a substantial change in structure, over a long period, starting in an era when the country was poor, all the way to prosperity (e.g., Sweden) ${ }^{46}$ tends to coincide with dramatic changes in government policy ${ }^{47}$ Can groups ever die peacefully? We are not sure. One of the few examples of such a process is provided by Jones (2000), who describes the demise (or refocus) of British trading houses during recent decades in response to a changing environment (rise of diversified institutional investors in London, decolonization abroad, decline in trade in raw materials, etc.). Morck et al. (2005) show that Canadian pyramids died peacefully in the mid twentieth century due to market crashes, inheritance taxes, and other factors, but new groups arose to replace them in the later decades of the century. There is also some recent evidence on the on-going, gradual decline of cross shareholding in Japanese corporate groups (Okabe 2002; Yafeh 2003; Miyajima and Kuroki, forthcoming). By contrast, recent evidence suggests that the business group phenomenon in much of East Asia did not disappear following the 1997 crisis, although some groups did collapse and others were forced to restructure. For example, Chung and Mahmood (2006) show that Taiwanese groups became more diversified both across industries and across countries following the crisis; they also became more pyramidal in structure. TsuiAuch (2006) examines both government owned and privately owned groups controlled by ethnic Chinese in Singapore, finding certain gradual changes toward increased focus but much continuity. Gomez (2006) documents significant weakening of Malaysian groups with the demise of their patrons, Prime Minister Mahathir and other politicians in Malaysia, like Daim and Anwar. Polsiri and Wiwattanakantang (2006) describe the restructuring of Thai business groups and Hanani (2006) of Indonesian groups. None of these studies suggests that, despite the crisis and the ensuing changes, the dissolution of business groups in any of these countries is imminent. Are there cultural or societal reasons that would prevent corporate structure in emerging markets from self-evolving into a more focused structure as the country devel-

\footnotetext{
${ }^{46}$ For a brief discussion of the history and survival of the Wallenberg group, the largest in Sweden, over the past 150 years, see the Economist, Oct. 14, 2006, p. 94

${ }^{47}$ For example, President Roosevelt deliberately attempted to dismantle American big businesses during the Great Depression (Morck 2005; Morck and Yeung 2005), which may explain why he could muster the necessary political will. The American occupation authorities forcefully dissolved the Japanese zaibatsu after World War II (Yafeh 1995). The South Korean government attempted to curb the power of the major chaebol following the Asian financial crisis of 1997â98 (Khanna and Palepu 1999b; Chang 2003a) with limited success.
} 
ops? What is the role of government in this process? Is it advisable, or even possible, for the state to forcibly dismantle groups, as has been attempted in South Korea? Even if groups have run their course, is it clear that the desired policy is to try and dissolve them (Khanna and Palepu 1999b)? Is a policy of benign neglect more desirable (as in India)? Is it clear that when the social costs of corporate groups exceed their social benefits, private costs to group owners will also exceed private benefits? Can groups involving substantial inefficiencies persist for a long time? If so, is it because of a weak corporate control environment? Because of social reasons (e.g., families who diversify to accommodate disparate interests of the next generation)? These are complex theoretical issues. At present, we are aware of only one study that tries to address them: Almeida and Wolfenzon (2006) argue that because of negative externalities (on the ability of nongroup firms to raise finance) business groups do not realize the full cost of their presence (and presumably will not dissolve on their own even when it is optimal to do so).

\subsection{Counterfactuals to Business Groups}

When considering the welfare consequences of groups, it is unclear what the appropriate counterfactual should be: against what alternative should groups be evaluated? The ideal is a well functioning market economy, but in reality the world consists of distant second-bests. In the absence of groups, would there be other forms of networks? Would market-supporting institutions emerge spontaneously? Is there a way to infer the appropriate counterfactual from recent policy interventions (e.g., in South Korea or China)? Almeida and Wolfenzon (2006), who evaluate the welfare implications of business groups as a function of measures of efficiency of external financial markets, provide an interesting starting point for addressing this issue. Also relevant is the model of Maksimovic and Phillips (2002), who suggest that conglomerates are an efficient equilibrium outcome to certain business opportunities, whereas for others standalone firms are better suited. The equivalent for business groups would be that groups are an efficient outcome for certain situations in which the appropriate counterfactual is not necessarily stand alone firms but some other, not well specified, outcome. Also related is the observation in Maurer and Haber (2006) that, when restrictions were imposed on related lending within Mexican business groups in 1997, the result was a large decline in the size of the credit market, not the emergence of a competitive equilibrium in which all firms could access loans on equal footing.

Conceivably, the relevant counterfactual to business groups may change with economic development - in early stages, in the absence of groups, the plausible feasible alternative may well be underdevelopment and limited market institutions. In more advanced economies, in the absence of business groups, perhaps superior capital, labor, and other market institutions 
would develop; this conjecture has never been tested.

\subsection{Groups and Macroeconomic Crises}

Some studies relate corporate governance in business groups to the financial crisis in East Asia (e.g., Corsetti et al., 1999; Johnson et al., 2000; Mitton 2002; Kim and Lee 2003; Baek et al. 2004) Somewhat related is the argument that crony capitalism enabled groups to borrow particularly easily, and moral hazard problems associated with this may have precipitated the crisis (Charumilind et al., 2006). The popular press, especially in South Korea, echoes these concerns. But are countries whose economies are dominated by business groups more crisis prone than countries characterized by stand alone companies? Is it the case that, if a few families control a large fraction of an economy through business groups, microeconomic governance or management difficulties may turn into macroeconomic problems? On theoretical grounds, this is uncertain - links between group firms may propagate adverse shocks, but mutual insurance within groups can sometimes dampen them (Khanna and Yafeh 2005). Empirically, the ubiquity of business groups may render such an exercise difficult, but this line of research has potentially important welfare and policy implications.

To conclude, we believe that any blanket characterization of business groups as either paragons or parasites would be unwarranted, both because of the nature of the existing evidence and because of the continued existence of unanswered puzzles. Part of the difficulty stems from the vast differences across countries, groups, and time periods, and part from the multiple effects that groups tend to have. Progress is likely to result from casting a broader net for relevant data; this includes paying attention to historical data and evidence, using group origin as a relevant variable, and exploiting time series variation. To us, business groups continue to be a fascinating topic for research, still posing many interesting questions with implications for a variety of important issues in economics and finance.

\footnotetext{
${ }^{48}$ Claessens et al. (2006) is also related: they argue that within-group internal capital markets do not function well in crisis periods.
} 


\section{References}

Abramitzky, R., 2005. The Limits of Equality: An Economic Analysis of the Israeli Kibbutz. Unpublished.

Acemoglu, D., Simon J., Mitton, T., 2005. Determinants of Vertical Integration: Finance, Contracts, and Regulation. NBER Working Paper 11424.

Aganin, A., Volpin, P., 2005. The History of Corporate Ownership in Italy. In Morck, R., (Ed.), A History of Corporate Governance around the World: Family Business Groups to Professional Managers, University of Chicago Press, Chicago, pp.325-361.

Almeida, H., Wolfenzon, D., 2006. Should Business Groups Be Dismantled? The Equilibrium Costs of Efficient Internal Capital Markets. Journal of Financial Economics 79, 99-144. doi:10.1016/j.jfineco.2005.02.001

Almeida, H., Wolfenzon, D., A Theory of Pyramidal Ownership and Family Business Groups. Journal of Finance 41, 2637-2680.

Amatori, F., 1997. Growth via Politics: Business Groups Italian-Style. In Shiba, T., Shimotani, M., (Eds.), Beyond the Firm: Business Groups in International and Historical Perspective, Oxford University Press, Oxford, pp. 109-134.

America Economica, 1997. Los Principales Conglomerados. Madrid, Dow Jones.

Amihud, Y., and Baruch, L., 1981. Risk Reduction as a Managerial Motive for Conglomerate Mergers. Bell Journal of Economics 12, 605-617. doi: $10.2307 / 3003575$

Amsden, A.H., 1989. Asia's Next Giant: South Korea and Late Industrialization. Oxford University Press, New York and Oxford.

Aoki, M., 2001. Toward a Comparative Institutional Analysis. Comparative Institutional Analysis Series, MIT Press, Cambridge and London.

Bae, K.-H., Jun-Koo K., Kim, J.-M. 2002. Tunneling or Value Added? Evidence from Mergers by Korean Business Groups. Journal of Finance 57, 2695-2740. doi: 10.1111/1540-6261.00510

Baek, J.-S., Kang J.-K., Lee, I., 2006. Business Groups and Tunneling: Evidence from Private Securities Offerings by Korean Chaebols. Journal of Finance 61, 2415-2449. doi: 10.1111/j.1540-6261.2006.01062.x

Baek, J.-S., Kang J.-K., Park, K.S., 2004. Corporate Governance and Firm Value: Evidence from the Korean Financial Crisis. Journal of Financial Economics 71, 265-313. doi: 10.1016/S0304-405X(03)00167-3 
Baker, G.P., Montgomery, C.M., 1994. Conglomerates and LBO Associates: A Comparison of Organizational Forms. Unpublished.

Barca, F., Becht, M., 2001. The Control of Corporate Europe. (Eds.) Oxford, Oxford University Press.

Barontini, R., Caprio. L., 2005. The Effect of Family Control on Firm Value and Performance: Evidence from Continental Europe. ECGI Finance Working Paper 88/2005.

Bebchuk, L.A., Kraakman, R., Triantis G.G., 2000. Stock Pyramids, CrossOwnership, and Dual Class Equity: The Mechanisms and Agency Costs of Separating Control from Cash-Flow Rights. In Morck, R., (Eds.) Concentrated Corporate Ownership, NBER Conference Report series, Chicago and London, University of Chicago Press, pp. 295-315.

Bennedsen, M., Nielsen, K.M., 2006. The Principle of Proportional Ownership, Investor Protection and Firm Value in Western Europe. Unpublished.

Berger, P.G., Ofek, E., 1995. Diversification's Effect on Firm Value. Journal of Financial Economics 37, 39-65. doi: 10.1016/0304-405X(94)00798-6

Berle, A., Means, G., 1932. The Modern Corporation and Private Property. New York, MacMillan.

Bernheim, B.D., Whinston, M.D., 1990. Multimarket Contact and Collusive Behavior. RAND Journal of Economics 21, 1-26. doi: 10.2307/2555490

Bertrand, M., Johnson, S. Samphantharak, K., Schoar, A., 2004. Mixing Family with Business: A Study of Thai Business Groups and the Families behind Them. Unpublished.

Bertrand, M., Mehta, P., Mullainathan, S., 2002. Ferreting Out Tunneling: An Application to Indian Business Groups. Quarterly Journal of Economics 117, 121-148. doi: 10.1162/003355302753399463

Bhagwati, J.N., 1982. Directly Unproductive, Profit-Seeking (DUP) Activities. Journal of Political Economy 90, 988-1002. doi: 10.1086/261104

Bianchi, M., Bianco, M., Enriques, L., 2001. Pyramidal Groups and the Separation between Ownership and Control in Italy. In F. Barca, F., Becht, M., (Eds.). The Control of Corporate Europe, Oxford, Oxford University Press, pp. 154-187.

Bianco, M., Nicodano, G., 2006. Pyramidal Groups and Debt. European Economic Review 50, 937-961. doi:10.1016/j.euroecorev.2004.11.001 
Borensztein, E., Lee, J.-W., 2002. Financial Crisis and Credit Crunch in Korea: Evidence from Firm-Level Data. Journal of Monetary Economics 49, 853-875. doi: 10.1016/S0304-3932(02)00116-2

Bunkanwanicha, P., Wiwattanakantang, Y., 2005. Tycoons Turned Leaders: Investigating the Incentives for Holding Public Office. Unpublished.

Buysschaert, A., Deloof, M., Jegers, M., 2004. Equity Sales in Belgian Corporate Groups: Expropriation of Minority Shareholders? A Clinical Study. Journal of Corporate Finance 10, 81-103. doi:10.1016/S0929-1199(02)000470

Campa, J.M., Kedia, S., 2002. Explaining the Diversification Discount. Journal of Finance 57, 1731-1762. doi:10.1111/1540-6261.00476

Campbell II, T.L., Keys, P.Y., 2002. Corporate Governance in South Korea: The Chaebol Experience. Journal of Corporate Finance 8, 373-391. doi:10.1016/S0929-1199(01)00049-9

Cestone, G., Fumagalli, C., 2005. The Strategic Impact of Resource Flexibility in Business Groups. RAND Journal of Economics 36, 193-214.

Chang, J.J., Shin, H.-H., 2005. Does the Family Portfolio Perform Better than the Group Portfolio? Evidence from Korean Conglomerates. Unpublished.

Chang, S.-J., 2003a. Financial Crisis and Transformation of Korean Business Groups: The Rise and Fall of Chaebols. Cambridge, New York and Melbourne, Cambridge University Press. doi:10.1017/CBO9780511510861

Chang, S.-J., 2003b. Ownership Structure, Expropriation and Performance of Group-Affiliated Companies in Korea. Academy of Management Journal 46, 238-254. doi:10.2307/30040617

Chang, S.-J., 2006. Korean Business Groups: The Financial Crisis and the Restructuring of Chaebols. In Chang. S.-J., (Ed.), Business Groups in East Asia: Financial Crisis, Restructuring, and New Growth, Oxford, Oxford University Press, pp. 52-69. doi:10.1093/acprof:oso/9780199287345.003.0003

Chang, S.-J., Choi, U., 1988. Strategy, Structure and Performance of Korean Business Groups: A Transactions Cost Approach. Journal of Industrial Economics 37, 141-158. doi:10.2307/2098561

Chang, S.-J., Hong, J., 2000. Economic Performance of Group-Affiliated Companies in Korea: Intra-group Resource Sharing and Internal Business Transactions. Academy of Management Journal 43, 429-448. doi:10.2307/1556403 
Chang, S.-J., Hong, J., 2002. How Much Does the Business Group Matter in Korea? Strategic Management Journal 23, 265-274. doi:10.1002/smj.224

Chari, A., Gupta, N, 2006. Incumbents and Protectionism: The Political Economy of Foreign Entry Liberalization. Unpublished.

Charumilind, C., Kali, R., Wiwattanakantang, Y., 2006. Connected Lending: Thailand before the Financial Crisis. Journal of Business 79, 181-217. doi: $10.1086 / 497410$

Cheung, Y.-L., Rau, P.R., Stouraitis, A., 2006. Tunneling, Propping, and Expropriation: Evidence from Connected Party Transactions in Hong Kong. Journal of Financial Economics 82, 343-386. doi:10.1016/j.jfineco.2004.08.012

Chevalier, J., 2004. What Do We Know About Cross-Subsidization? Evidence from Merging Firms. Advances in Economic Analysis and Policy 4, 1-27. doi:10.2202/1538-0637.1218

Choi, J.-P., Cowing, T.J., 1999. Firm Behavior and Group Affiliation: The Strategic Role of Corporate Grouping for Korean Firms. Journal of Asian Economics 10, 195-209. doi:10.1016/S1049-0078(99)00014-7

Chung, C.N., 2001. Markets, Culture and Institutions: The Emergence of Large Business Groups in Taiwan, 1950s-1970s. Journal of Management Studies 38, 719-745. doi:10.1111/1467-6486.00256

Chung, C.N., 2006. Beyond Guanxi: Network Contingencies in Taiwanese Business Groups. Organization Studies 27, 461-489. doi:10.1177/0170840605058230

Chung, C.N., Mahmood, I., 2006. Taiwanese Business Groups: Steady Growth in Institutional Transition. In Chang, S-J., (Ed.). Business Groups in East Asia: Financial Crisis, Restructuring, and New Growth, Oxford, Oxford University Press, pp. 70-93.

Claessens, S., Djankov, S., Lang, L.H.P., 2000. The Separation of Ownership and Control in East Asian Corporations. Journal of Financial Economics 58, 81-112. doi:10.1016/S0304-405X(00)00067-2

Claessens, S., Djankov, S., Fan, J.P.H., Lang, L.H.P., 2002. Disentangling the Incentive and Entrenchment Effects of Large Shareholdings. Journal of Finance 57, 2741-2771. doi: 10.1111/1540-6261.00511

Claessens, S., Djankov, S., Fan, J.P.H., Lang, L.H.P., 2003. When Does Corporate Diversification Matter to Productivity and Performance? Evidence from East Asia. Pacific- Basin Finance Journal 11, 365-392. doi:10.1016/S0927-538X(03)00029-5 
Claessens, S., Fan, J.P.H., Lang, L.H.P., 2006. The Benefits and Costs of Group Affiliation: Evidence from East Asia. Emerging Markets Review 7, 1-26. doi:10.1016/j.ememar.2005.08.001

Clifford, M.L., 1994. Troubled Tiger: Businessmen, Bureaucrats, and Generals in South Korea. New York, Sharpe.

Comment, R., Jarrell, G.A., 1995. Corporate Focus and Stock Returns. Journal of Financial Economics 37, 67-87. doi:10.1016/0304-405X(94)00777-X

Commonwealth of Australia, Department of Foreign Affairs, East Asia Analytical Unit. 1995. Overseas Chinese Business Networks in Asia. Parkes, Commonwealth of Australia, Department of Foreign Affairs and Trade.

Corsetti, G., Pesenti, P., Roubini, N., 1999. What Caused the Asian Currency and Financial Crisis? Japan and the World Economy 11, 305-373. doi:10.1016/S0922-1425(99)00019-5

Cull, R., Haber, S., Imai, M., 2006. All Bad, All of the Time? Related Lending and Financial Development. Unpublished.

De Long, Bradford, J., 1991. Did J. P. Morgan's Men Add Value? An Economist's Perspective on Financial Capitalism. In Temin. P., (Ed.). Inside the Business Enterprise: Historical Perspectives on the Use of Information, A National Bureau of Economic Research Conference Report Chicago and London, University of Chicago Press, pp. 205-236.

Desai, M.A., Dyck, A., Zingales, L., 2007. Theft and Taxes. Journal of Financial Economics.

Dyck, A., Zingales, L., 2004. Private Benefits of Control: An International Comparison. Journal of Finance 59, 537-600. doi:10.1111/j.15406261.2004.00642.x

Encaoua, D., Jacquemin, A., 1982. Organizational Efficiency and Monopoly Power: The Case of French Industrial Groups. European Economic Review 19, 25-51. doi:10.1016/0014-2921(82)90004-6

Faccio, M., 2006. Politically Connected Firms. American Economic Review 96, 369-386. doi:10.1257/000282806776157704

Faccio, M., Lang, L.H.P., 2002. The Ultimate Ownership of Western European Corporations. Journal of Financial Economics 65, 365-395. doi:10.1016/S0304-405X(02)00146-0

Faccio, M., Lang, L.H.P., Young, L., 2001. Dividends and Expropriation. American Economic Review 91, 54-78. doi:10.1257/aer.91.1.54 
Fan, J.P.H., Huang, J., Morck, R., Yeung, B., 2006. Institutional Determinants of Vertical Integration: Evidence from China. Unpublished.

Faure-Grimaud, A., Inderst, R., 2005. Conglomerate Entrenchment under Optimal Financial Contracting. American Economic Review 95, 850-861. doi: $10.1257 / 0002828054201260$

Fauver, L., Houston, J., Naranjo, A., 2003. Capital Market Development, International Integration, Legal Systems, and the Value of Corporate Diversification: A Cross-Country Analysis. Journal of Financial and Quantitative Analysis 38, 135-157. doi:10.2307/4126767

Fazzari, S.M., Hubbard, R.G., Petersen, B.C., 1988. Financing Constraints and Corporate Investment. Brookings Papers on Economic Activity 1, 141195. doi:10.2307/2534426

Feenstra, R.C., Hamilton, G.G., 2006. Emergent Economies, Divergent Paths: Economic Organization and International Trade in South Korea and Taiwan. Structural Analysis in the Social Sciences series, vol. 29. Cambridge and New York, Cambridge University Press. doi:10.1017/CBO9780511499586

Feenstra, R.C., Huang, D.-S., Hamilton, G.G., 2003. A Market-Power Based Model of Business Groups. Journal of Economic Behavior and Organization 51, 459-485. doi:10.1016/S0167-2681(02)00181-6

Ferris, S.P., Kim, K.A., Kitsabunnarat, P., 2003. The Costs (and Benefits?) of Diversified Business Groups: The Case of Korean Chaebols. Journal of Banking and Finance 27, 251-73. doi:10.1016/S0378-4266(01)00248-5

Fisman, R., 2001. Estimating the Value of Political Connections. American Economic Review 91, 1095-1102. doi:10.1257/aer.91.4.1095

Fisman, R., Khanna, T., 2004. Facilitating Development: The Role of Business Groups. World Development 32, 609-628. doi:10.1016/j.worlddev.2003.08.012

Fogel, K., 2006. Oligarchic Family Control, Social Economic Outcomes, and the Quality of Government. Journal of International Business Studies 37, 603-622.

Franks, J., Mayer, C., Miyajima, H., 2006. Evolution of Ownership: The Curious Case of Japan. Unpublished.

Gerlach, M.L., 1992. Alliance Capitalism: The Social Organization of Japanese Business. Berkeley and Oxford, University of California Press. 
Ghatak, M., Kali, R., 2001. Financially Interlinked Business Groups. Journal of Economics and Management Strategy 10, 591-619. doi:10.1162/105864001753356114

Ghemawat, P., Khanna, T., 1998. The Nature of Diversified Business Groups: A Research Design and Two Case Studies. Journal of Industrial Economics 46, 35-61. doi:10.1111/1467-6451.00060

Gomes, A., 2000. Going Public without Governance: Managerial Reputation Effects. Journal of Finance 55, 615-646. doi:10.1111/0022-1082.00221

Gomez, E. T., 2006. Malaysian Business Groups: The State and Capital Development in the Post-currency Crisis Period. In Chang, S.J., (Ed.), Business Groups in East Asia: Financial Crisis, Restructuring and New Growth, Oxford, Oxford University Press, pp. 119-146. doi:10.1093/acprof:oso/9780199287345.003.0006

Gomez, E.T., Jomo, K.S., 1999. Malaysia's Political Economy: Politics, Patronage and Profits. Second edition. Cambridge, Cambridge University Press.

Gomez-Galvarriato, A. Forthcoming. The Political Economy of Protectionism: The Mexican Textile Industry, 1900-1950. In Edwards, S., (Ed.), Growth, Institutions and Crises: Latin America from a Historic Perspective, Chicago, University of Chicago Press.

Gompers, P., Lerner, J., Scharfstein, D.S., 2005. Entrepreneurial Spawning: Public Corporations and the Genesis of New Ventures, 1986 to 1999. Journal of Finance 60, 577-614. doi:10.1111/j.1540-6261.2005.00740.x

Gopalan, R., Nanda, V.K., Seru, A., forthcoming. Reputation and Spillovers: Evidence from Indian Business Groups. Journal of Financial Economics.

Granovetter, M., 2005. Business Groups and Social Organization. In Smelser, N., Swedberg, R., (Eds.), The Handbook of Economic Sociology, Second edition, Princeton, Princeton University Press, pp. 429-450.

Greif, A., 2006. Institutions and the Path to the Modern Economy: Lessons from Medieval Trade. Cambridge, Cambridge University Press. doi:10.1017/CBO9780511791307

Greif, A., Kandel, E., 1995. Contract Enforcement Institutions: Historical Perspective and Current Status in Russia. In Lazear, E., (Ed.), Economic Transition in Eastern Europe and Russia: Realities of Reform, Stanford, Hoover Institution Press, pp. 291-321.

Guriev, S., Rachinsky, A., 2005. The Role of Oligarchs in Russian Capitalism. Journal of Economic Perspectives 19, 131-150. doi:10.1257/0895330053147994 
Hadley, E.M., 1970. Antitrust in Japan. Princeton, Princeton University Press.

Hamilton, G.G., 1997. Organization and Market Processes in Taiwan's Capitalist Economy. In Orru, M., Biggart, N.W., Hamilton, G.G., (Eds.). The Economic Organization of East Asian Capitalism, Thousand Oaks, Calif,; London and New Delhi, Sage Publications, pp. 237-293.

Hamilton, G.G., Feenstra, R.C., 1997. Varieties of Hierarchies and Markets: An Introduction. In Orru, M., Biggart, N.W., Hamilton, G.G., (Eds.), The Economic Organization of East Asian Capitalism, Thousand Oaks, Calif, London and New Delhi, Sage Publications, pp. 55-94.

Hanani, A., 2006. Indonesian Business Groups: The Crisis in Progress. In Chang, S.-J., (Ed.), Business Groups in East Asia: Financial Crisis, Restructuring, and New Growth, Oxford, Oxford University Press, pp. 179-204. doi:10.1093/acprof:oso/9780199287345.003.0008

Holmen, M, HÃ $q$ gfeldt, P., 2005. Pyramidal Discounts: Tunneling or Agency Costs? Unpublished.

Hoshi, T., Kashyap, A., Scharfstein, D.S., 1991. Corporate Structure, Liquidity, and Investment: Evidence from Japanese Industrial Groups. Quarterly Journal of Economics 106, 33-60. doi:10.2307/2937905

Huang, Y., 2003. Selling China: Foreign Direct Investment during the Reform Era. Cambridge, Cambridge University Press.

Hubbard, R.G., Palia, D., 1999. A Reexamination of the Conglomerate Merger Wave in the 1960s: An Internal Capital Markets View. Journal of Finance 54, 1131-1152. doi:10.1111/0022-1082.00139

Joh, S.W., 2003. Corporate Governance and Firm Profitability: Evidence from Korea before the Economic Crisis. Journal of Financial Economics 68, 287-322. doi:10.1016/S0304-405X(03)00068-0

Johnson, J., 1997. Russia's Emerging Financial- Industrial Groups. PostSoviet Affairs 13, 333-365.

Johnson, S., Boone, P., Breach, A., Friedman, E., 2000. Corporate Governance in the Asian Financial Crisis. Journal of Financial Economics 58, 141-186. doi:10.1016/S0304-405X(00)00069-6

Johnson, S., La Porta, R., Lopez-de-Silanes, F., Shleifer, A., 2000. Tunneling. American Economic Review 90, 22-27. doi:10.1257/aer.90.2.22

Johnson, S., Mitton, T., 2003. Cronyism and Capital Controls: Evidence from Malaysia. Journal of Financial Economics 67, 351-382. doi:10.1016/S0304405X(02)00255-6 
Jones, G., 2000. Merchants to Multinationals: British Trading Companies in the Nineteenth and Twentieth Centuries. Oxford and New York, Oxford University Press.

Jones, G., Khanna, T., 2006. Bringing History (Back) into International Business. Journal of International Business Studies 37, 453-468. doi:10.1057/palgrave.jibs.8400198

Kali, R., 1999. Endogenous Business Networks. Journal of Law, Economics, and Organization 15, 615-636. doi:10.1093/jleo/15.3.615

Kali, R. 2003. Business Groups, the Financial Market and Modernization. Economics of Transition 11, 671-696. doi: 10.1111/j.0967-0750.2003.00160.x

Kang, C. -K. 1997., Diversification Process and the Ownership Structure of Samsung Chaebol. In Shiba T. Shimotani, M., (Eds.) Beyond the Firm: Business Groups in International and Historical Perspective, Oxford, Oxford University Press, 31-58.

Karademir, B., Danisman, A., 2006. Business Groups and Media in Emerging Economies: A Co-evolutionary Approach to Their Interrelationship in Turkey, 1960-2005. Paper Presented at the 23rd European Group for Organizational Studies Colloquium.

Bahattin, K., Ãzgen, H., Osborn, R.N., Yaprak, A., 2005. The Co-evolution of Institutional Environments, Markets, Organizational Capabilities, and Organization Strategies: A Historical and Comparative Study of Turkish Family Holdings. Proceedings of the 21st European Group for Organizational Studies Colloquium.

Keister, L.A., 1998. Engineering Growth: Business Group Structure and Firm Performance in China's Transition Economy. American Journal of Sociology 104, 404-440. doi: 10.1086/210043

Keister, L.A., 2004. Chinese Business Groups: The Structure and Impact of Interfirm Relations during Economic Development. Oxford, Oxford University Press.

Khanna, T., 2000. Business Groups and Social Welfare in Emerging Markets: Existing Evidence and Unanswered Questions. European Economic Review 44, 748-761. doi: 10.1016/S0014-2921(99)00059-8

Khanna, T., Palepu, K., 1997. Why Focused Strategies May Be Wrong for Emerging Markets. Harvard Business Review 75, 41-51.

Khanna, T., Palepu, K., 1999a. Policy Shocks, Market Intermediaries, and Corporate Strategy: The Evolution of Business Groups in Chile and India. Journal of Economics and Management Strategy 8, 271-310. doi:10.1257/0895330053147994 
Khanna, T., Palepu, K., 1999b. The Right Way to Restructure Conglomerates in Emerging Markets. Harvard Business Review 77, 125-134.

Khanna, T., Palepu, K., 2000a. Emerging Market Business Groups, Foreign Intermediaries, and Corporate Governance. In R. Morck (Ed.) A History of Corporate Governance around the World: Family Business Groups to Professional Managers, University of Chicago Press, Chicago, pp. 265-92.

Khanna, T., Palepu, K., 2000b. Is Group Affiliation Profitable in Emerging Markets? An Analysis of Diversified Indian Business Groups. Journal of Finance 55, 867-891. doi: 10.1111/0022-1082.00229

Khanna, T., Palepu, K., 2000c. The Future of Business Groups in Emerging Markets: Long-Run Evidence from Chile. Academy of Management Journal 43, 268-285. doi: 10.2307/1556395

Khanna, T., Palepu, K., 2005. The Evolution of Concentrated Ownership in India: Broad Patterns and a History of the Indian Software Industry. In R. Morck (Ed.) A History of Corporate Governance around the World: Family Business Groups to Professional Managers, University of Chicago Press, Chicago, pp. 283-320.

Khanna, T., Palepu, K., Wu, D.M., 1995. The House of Tata, 1995: The Next Generation (A). Harvard Business School Case 9, 798-037.

Khanna, T., Rivkin, J.W., 2001. Estimating the Performance Effects of Business Groups in Emerging Markets. Strategic Management Journal 22, 4574. doi: 10.1002/1097-0266(200101)22:1;45::AID-SMJ147¿3.0.CO;2-F

Khanna, T., Thomas, C, 2004. What Type of Control Group Causes Stock Price Synchronicity? Unpublished.

Khanna, T., Yafeh, Y., 2005. Business Groups and Risk Sharing around the World. Journal of Business 78, 301-40. doi: 10.1086/426527

Kim, B., Inmoo L., 2003. Agency Problems and Performance of Korean Companies during the Asian Financial Crisis: Chaebol vs. Non- Chaebol Firms. Pacific-Basin Finance Journal 11, 327-348. doi: 10.1016/S0927538X(03)00027-1

Kim, E.M., 1997, Big Business, Strong State: Collusion and Conflict in South Korean Development, 1960-1990. Albany, SUNY Press.

Kim, E., 2006. The Impact of Family Ownership and Capital Structures on Productivity Performance of Korean Manufacturing Firms: Corporate Governance and the 'Chaebol Problem.' Journal of the Japanese and International Economies 20, 209-233. doi: 10.1016/j.jjie.2005.02.001 
Kim, S-J., 2004. Bailout and Conglomeration. Journal of Financial Economics 71, 315-347. doi: 10.1016/S0304-405X(03)00191-0

Kim, W., Lim, Y., Sung, T.. 2004. What Determines the Ownership Structure of Business Conglomerates? On the Cash Flow Rights of Korea's Chaebol. ECGI Finance Working Paper, no. 051/2004.

Kompass Indonesia. 1996. Top Companies and Big Groups in Indonesia. Jakarta: Kompass Indonesia.

Krueger, A.O. 1974. The Political Economy of the Rent-Seeking Society. American Economic Review 64, 291-303.

Kurgan-Van Hentenryk, G., 1997. Structure and Strategy of Belgian Business Groups (1920-1990). In Shiba T. Shimotani, M., (Eds.) Beyond the Firm: Business Groups in International and Historical Perspective, Oxford University Press, Oxford, pp. 88-108.

La Porta, R., Lopez-de-Silanes, F., Shleifer, A., 1999. Corporate Ownership around the World. Journal of Finance 54, 471-517. hrefhttp:/ /dx.doi.org/10.1111/0022-1082.00115doi: $\quad 10.1111 /$ j.15406261.1997.tb02727.x

La Porta, R., Lopez-de-Silanes, F., Shleifer, A., Vishny, R.W., 1997. Legal Determinants of External Finance. Journal of Finance 52, 1131-1150. hrefhttp://dx.doi.org/10.1111/j.1540-6261.1997.tb02727.xdoi: 10.1111/j.1540-6261.1997.tb02727.x

La Porta, R., Lopez-de-Silanes, F., Shleifer, A., Vishny, R.W., 1998. Law and Finance. Journal of Political Economy 106, 1113-1155. hrefhttp:/ /dx.doi.org/10.1086/250042doi: 10.1086/250042

La Porta, R., Lopez-de-Silanes, F., Zamarripa, G., 2003. Related Lending. Quarterly Journal of Economics 118, 231$268 . \quad$ hrefhttp://dx.doi.org/10.1162/00335530360535199doi: $10.1162 / 00335530360535199$

Lamoreaux, N.R., 1994. Insider Lending: Banks, Personal Connections, and Economic Development in Industrial New England. NBER Series on Long- term Factors in Economic Development. Cambridge University Press, Cambridge; New York and Melbourne. $\quad$ hrefhttp://dx.doi.org/10.1017/CBO9780511582523doi: 10.1017/CBO9780511582523

Lang, L.H.P., Stulz, R.M., 1994. Tobin's Q, Corporate Diversification, and Firm Performance. Journal of Political Economy 102, 1248-1280. doi:10.1086/261970 
Lee C.H., Keun, L., Kangkook L., 2002. Chaebols, Financial Liberalization and Economic Crisis: Transformation of Quasi-Internal Organization in Korea. Asian Economic Journal 16, 17-35. doi: 10.1111/1467-8381.00140

Lee,K., Lee, D.G., 2002. The Dark Side of Internal Capital Allocation: The Case of Korean Chaebols. Seoul Journal of Economics, 15, 321-368.

Lee, K., Peng, M., Lee, K., 2001. Institutions and Changing Performance of Corporate Groups: The Case of the Chaebols in Korea. Unpublished.

Lee, K., Ryu, K., Yoon, J.M., 2000. Productive Efficiency of Chaebols and Non- Chaebol Firms in Korea: Stochastic Production Frontier Estimation Using Panel Data. Unpublished.

Leff, N.H., 1976. Capital Markets in Less Developed Countries: The Group Principle. In McKinnon, R., (Ed.), Money and Finance in Economic Growth and Development: Essays in Honour of Edward S. Shaw, Decker Press, New York, pp.97-122.

Leff, N.H., 1978. Industrial Organization and Entrepreneurship in the Developing Countries: The Economic Groups. Economic Development and Cultural Change 26, 661-675. doi: 10.1086/451052

Leuz, C., Lins,K.V, Warnock, F.E., 2006. Do Foreigners Invest Less in Poorly Governed Firms? NBER Working Papers, no. 12222.

Leuz, C., Oberholzer-Gee, F., 2006. Political Relationships, Global Financing, and Corporate Transparency: Evidence from Indonesia. Journal of Financial Economics 81, 411-439. doi: 10.1016/j.jfineco.2005.06.006

Luo, X., Chung, C., Forthcoming. Keeping It All in the Family: The Role of the Particularistic Relationships in Business Group Performance during Institutional Transition. Administrative Science Quarterly.

Majluf, N., Abarca, N., RodrÃguez, D., Fuentes, L.A., 1995. The Ownership of Economic Groups in Chile. Unpublished.

Maksimovic, V., Phillips, G., 2002. Do Conglomerate Firms Allocate Resources Inefficiently across Industries? Theory and Evidence. Journal of Finance 57, 721-767. doi: 10.1111/1540-6261.00440

Maman, D., 2002. The Emergence of Business Groups: Israel and South Korea Compared. Organization Studies 23 737-758. doi: $10.1177 / 0170840602235003$

Mango, A., 2004. The Turks Today. Overlook Press, New York.

Manos, R., Murinde, V., Green, C.J., 2004. Business Groups and Capital Structure: Evidence from Indian Firms. Unpublished. 
Marisetty, V.B., Subrahmanyam, M.G., 2006. Group Affiliation and the Performance of Initial Public Offerings in the Indian Stock Market. Unpublished.

Martin, J.D., Sayrak, A., 2003. Corporate Diversification and Shareholder Value: A Survey of Recent Literature. Journal of Corporate Finance 9, 3757. doi: 10.1016/S0929-1199(01)00053-0

Matsusaka, J.G., 1993. Takeover Motives during the Conglomerate Merger Wave. RAND Journal of Economics 24, 357-379. doi: 10.2307/2555963

Maurer, N., 1999. Banks and Entrepreneurs in Porfirian Mexico: Inside Exploitation or Sound Business Strategy? Journal of Latin American Studies, 31(2): 331-61. doi: 10.1017/S0022216X99005301

Maurer, N., Haber, S., 2006. Related Lending and Economic Performance: Evidence from Mexico, 1888-1913. Unpublished.

Maurer, N., Sharma, T., 2001. Enforcing Property Rights through Reputation: Mexico's Early Industrialization, 1878-1913. Journal of Economic History 61, 950-973. doi: 10.1017/S0022050701042048

McDermott, G.A., 2002. Embedded Politics: Industrial Networks and Institutional Change in Postcommunism. University of Michigan Press, Ann Arbor.

McGregor, 1998. McGregor's Who Owns Whom in South Africa. McGregor Publishing, Auckland Park.

Mitton, T., 2002. A Cross-Firm Analysis of the Impact of Corporate Governance on the East Asian Financial Crisis. Journal of Financial Economics $64,215-241$.

Miyajima, H., Kuroki, F., Forthcoming. The Unwinding of CrossShareholding: Causes, Effects, and Implications. In Aoki, M., Jackson, G., Miyajima, H., (Eds.), Corporate Governance in Japan: Institutional Change and Organizational Diversity. Oxford University Press, Oxford.

Mobarak, A.M., and Purbasari, D., 2005. Political Trade Protection in Developing Countries: Firm Level Evidence from Indonesia. Unpublished.

Montgomery, C.A., 1994. Corporate Diversification. Journal of Economic Perspectives 8, 163-178. doi: 10.1257/jep.8.3.163

Morck, R., 2005. How to Eliminate Pyramidal Business Groups: The Double Taxation of Intercorporate Dividends and other Incisive Uses of Tax Policy. In Poterba, J., (Ed.), Tax Policy and the Economy, Vol. 19, MIT Press, Cambridge and London, pp. 135-179. 
Morck, R., Nakamura M., 2005. A Frog in a Well Knows Nothing of the Ocean: A History of Corporate Ownership in Japan. In Morck, R., (Ed.), A History of Corporate Governance around the World: Family Business Groups to Professional Managers. University of Chicago Press, Chicago, pp. 367-459.

Morck, R., Percy, M., Tian G.Y., Yeung, B.,. 2005. The Rise and Fall of the Widely Held Firm: A History of Corporate Ownership in Canada. In Morck, R., (Ed.), A History of Corporate Governance around the World: Family Business Groups to Professional Managers. University of Chicago Press, Chicago, pp. 65-140. doi: 10.7208/chicago/9780226536835.001.0001

Morck, R., Shleifer, A., Vishny R.W., 1990. Do Managerial Objectives Drive Bad Acquisitions? Journal of Finance 45, 31-48. doi: 10.1111/j.15406261.1990.tb05079.x

Morck, R., David, K., Stangeland, A., Yeung, B., 2000. Inherited Wealth, Corporate Control, and Economic Growth: The Canadian Disease? In Morck, R. (Ed.) Concentrated Corporate Ownership. NBER Conference Report series. University of Chicago Press, Chicago and London, pp. 319-369.

Morck, R., Wolfenzon, D., Yeung, B., 2005. Corporate Governance, Economic Entrenchment, and Growth. Journal of Economic Literature 43, 655720. doi: $10.2307 / 3003575$

Morck, R., Yeung, B., 2005. Dividend Taxation and Corporate Governance. Journal of Economic Perspectives 19, 163-180. doi: $10.1257 / 089533005774357752$

Morikawa, H., 1992. Zaibatsu: The Rise and Fall of Family Enterprise Groups in Japan. University of Tokyo Press, Tokyo.

Munshi, K., Rosenzweig, M., 2005. Economic Development and the Decline of Rural and Urban Community-Based Networks. Economics of Transition 13, 427-443. doi: 10.1111/j.1468-0351.2005.00231.x

Musacchio, A., 2004. Law and Finance in Historical Perspective: Politics, Bankruptcy Law and Corporate Governance in Brazil, 1850-2002. Unpublished.

Nenova, T., 2003. The Value of Corporate Voting Rights and Control: A Cross-Country Analysis. Journal of Financial Economics 68, 325-351. doi: $10.2307 / 3003575$

Nicodano, G., 2003. Bankruptcy Risk: Are Business Groups More Efficient than Conglomerates and Stand-Alone Units? Unpublished. 
Ohkawa, K., Rosovsky, H., 1973. Japanese Economic Growth: Trend Acceleration in the Twentieth Century. Stanford University Press, Stanford.

Okabe, M., 2002. Cross Shareholdings in Japan: A New Unified Perspective of the Economic System. Elgar, Cheltenham, U.K.

Orrù, M., Biggart, N.W., Hamilton, G.G., 1997. The Economic Organization of East Asian Capitalism. Thousand Oaks, Sage Publications, London and New Delhi.

Perkins, S., Morck, R., Yeung, B., 2006. Innocents Abroad: Failure Rates of International Joint Ventures with Firms in Pyramidal Groups. Unpublished.

Perotti, E.C., Gelfer, S., 2001. Red Barons or Robber Barons? Governance and Investment in Russian Financial-Industrial Groups. European Economic Review 45, 1601-1617. doi: 10.1016/S0014-2921(00)00097-0

Piramal, G., 1998. Business Legends. Viking Penguin, New Delhi.

Polsiri, P., Wiwattanakantang, Y., 2006. Thai Business Groups: Crisis and Restructuring. In Chang. S., (Ed.) Business Groups in East Asia: Financial Crisis, Restructuring, and New Growth. Oxford University Press, Oxford, pp. 147-178. doi: 10.1093/acprof:oso/9780199287345.003.0007

Rajan, R., Servaes, H., Zingales, L.. 2000. The Cost of Diversity: The Diversification Discount and Inefficient Investment. Journal of Finance 55, 35-80. doi: $10.1111 / 0022-1082.00200$

Rajan, R., Zingales, L. 2003. Saving Capitalism from the Capitalists: Unleashing the Power of Financial Markets to Create Wealth and Spread Opportunity. Random House, New York.

Roberts, J.G., 1973. Mitsui, Three Centuries of Japanese Business. Weatherhill, New York.

Samphantharak, K., 2003. Internal Capital Markets in Business Groups. Unpublished.

Scharfstein, D.S., Stein, J.C., 2000. The Dark Side of Internal Capital Markets: Divisional Rent-Seeking and Inefficient Investment. Journal of Finance 55, 2537-2564. doi: 10.1111/0022-1082.00299

Schwarz, A., 1994. A Nation in Waiting: Indonesia in the 1990s. Boulder: Westview Press, St. Leonards, New South Wales.

Shin, H., Park, Y.S., 1999. Financing Constraints and Internal Capital Markets: Evidence from Korean Chaebols.' Journal of Corporate Finance 5, 169191. doi: 10.1016/S0929-1199(99)00002-4 
Shin, H., Stulz R.M., 1998. Are Internal Capital Markets Efficient? Quarterly Journal of Economics 113, 531-552. doi: 10.2307/3003575

Shleifer, A., Vishny, R.W., 1997. A Survey of Corporate Governance. Journal of Finance 52, 737-783. doi: 10.1111/j.1540-6261.1997.tb04820.x

Shleifer, A., Wolfenzon, D., 2002. Investor Protection and Equity Markets. Journal of Financial Economics 66, 3-27. doi: 10.1016/S0304405X(02)00149-6

Siegel, J., 2006. Contingent Political Capital and International Alliances: Evidence from South Korea. Unpublished.

Stark, D., 1996. Recombinant Property in East European Capitalism. American Journal of Sociology 101, 993-1027. doi: 10.1086/230786

Steers, R.M., 1999. Made in Korea: Chung Ju Yung and the Rise of Hyundai. Routledge, New York.

Strachan, H.W., 1976. Family and other Business Groups in Economic Development: The Case of Nicaragua. Prager, New York.

Suzigan, W., Annibal V.V., 1997. Industrial Policy in Brazil. UNICAMP, Campinas.

Tara Siam Ltd. 1997. Thai Business Groups. Bangkok. Tara Siam Business Information Limited.

Tripathi, D., 2004. The Oxford Encyclopedia of Indian Business. Oxford University Press, Oxford.

Tsui-Auch, L.S., 2005. Unpacking Regional Ethnicity and the Strength of Ties in Shaping Ethnic Entrepreneurship. Organization Studies 26, 1189-1216. doi: $10.1177 / 0170840605055343$

Tsui-Auch, L.S., 2006. Singaporean Business Groups: The Role of the State and Capital in Singapore Inc. In Chang, S., (Ed.), Business Groups in East Asia: Financial Crisis, Restructuring, and New Growth, Oxford University Press, Oxford, 94-115. doi: 10.1093/acprof:oso/9780199287345.003.0005

Ungki, L., Chang-Soo, K., 2005. Determinants of Ownership Structure: An Empirical Study of the Korean Conglomerates. Pacific-Basin Finance Journal 13, 1-28. doi: 10.1016/j.pacfin.2003.11.001

Villalonga, B., 2004a. Diversification Discount or Premium? New Evidence from the Business Information Tracking Series. Journal of Finance 59, 479506. doi: $10.2307 / 3003575$ 
Villalonga, B., 2004b. Does Diversification Cause The 'Diversification Discount'? Financial Management 33, 5-27.

Weinstein, D.E., Yishay Y., 1995. Japan's Corporate Groups: Collusive or Competitive? An Empirical Investigation of Keiretsu Behavior. Journal of Industrial Economics 43, 359-376. doi: 10.2307/2950549

White, L.J., 1974. Industrial Concentration and Economic Power in Pakistan. Princeton University Press, Princeton.

Whited, T.M., 2001. Is It Inefficient Investment That Causes the Diversification Discount? Journal of Finance 56, 1667-1691. doi: 10.1111/00221082.00385

Yafeh, Y., 1995. Corporate Ownership, Profitability, and Bank-Firm Ties: Evidence from the American Occupation Reforms in Japan. Journal of the Japanese and International Economies 9, 154-173. doi: 10.1006/jjie.1995.1009

Yafeh, Y., 2003. An International Perspective of Corporate Groups and Their Prospects. In: Blomstrom, M., Corbett, J., Hayashi, F., Kashyap, A., (Eds.), Structural Impediments to Growth in Japan. University of Chicago Press, Chicago, pp. 259-284. doi: 10.7208/chicago/9780226060231.003.0010

Yaprak, A., Bahattin, K., Hüseyin, Ö., Richard N.O., 2004. Complex Configuations in the Turkish Economy. Proceedings of the Academy of International Business Annual Meeting.

Yurtoglu, B.B., 2000. Ownership, Control and Performance of Turkish Listed Firms. Empirica 27, 193-222. doi: 0.1023/A:1026557203261 